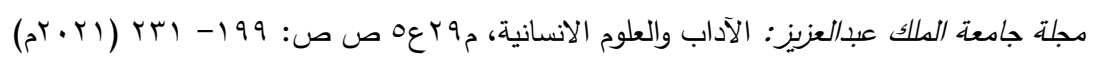

DOI:10.4197/Art.29-5.7

\title{
تصوير المعرفة والقيم في قصص الأطفال مجموعة دنيا الحكايا نموذجا
}

\author{
فتحية بنت السيد أحمد بليري \\ أستاذ اللغة المشارك \\ كلية اللغات والترجمة- جامعة جدة \\ ه إ \\ fabedair@uj.edu.sa
}

مستخلص. يمثل حضور الصورة بتعبيراتها ولمساتها الفنية في قصص الطفولة، بجانبيها المعرفي والقيمي، دوراً هاماً

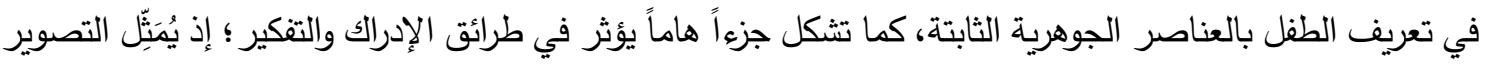
في قصص التراث بأساليب وطرائق شتى تسهم في إرساء القيم التربوية وتعزيزها، بما تحويه من جماليات دلالية في تعبيرها عن رغبات الطفل وحاجاته كونها رسائل من سارد القصص إلى الطفل تعمل على توجيهه. تحاول هذه الدراسة الوقوف على نزعة تعتمد العلوم المعرفية أساساً للمنهجية العلمية في التربية، في محاولة للموازنة بين القيم التربوية والجانب العلمي والوقوف على مدى موافقة تلك الصور الثقافة الطفل ومجتمعه ومقدرتها على التأثير في وجدانه لإشباع رغباته واحتياجاته، بالنظر إلى ما فيها من أوجه الحجاج والإقناع.

وتهدف هذه الدراسة إلى اكتثاف ما ما تحمله الصور من قيم وقوة حجاجية، والتعرف على إسهامها في تقريب المعرفة؛ لإحداث الهيمنة على فكر الطفل وسلوكياته، في سياق المقاربة المعرفية وفي إطار تفاعلي تبعاً لطرق وردها

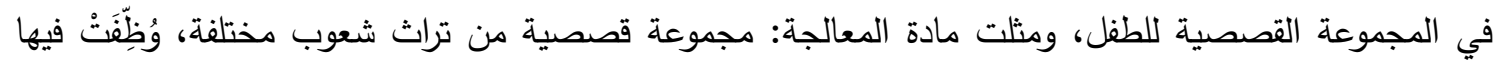

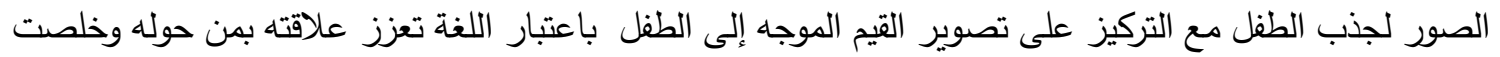
الدراسة إلى مجموعة من النتائج منها أن التحليل المعرفي للقصص يعطي معان عميقة والغاية من الوقوف عليه في بـ في القصص معرفة الآليات التي أسهمت في تزويد الطفل بقيم مختلفة، تؤكد على ضرورة تغيير السلوكيات غير المرغوب فيها، ونبذ العنف بمختلف الوسائل اللغوية وغير اللغوية. المقدمة: ننطلق في هذه الدراسة من فكرة مفادها أن على تقنية حتى تداهنا أخرى أحدث منها، ومع ذلك المعنى اللساني تصوريٌّ بالأساس، فلا نكاد نتعرف يبقى للقصص بريقها المعرفي خاصة إذا قدمت 


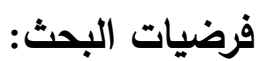

انطلق بحثنا من مجموعة من الفرضيات: - خصوصية الملامح التصويرية في قصص التراث، وانعكاس قيم الثعوب الأخرى في القصص. - انعكاس قيم تراث بعض الشعوب في القصص قد لد لا يتاسب مع ثقافة الطفل المجتمعية. - وجود ملامح عامة للعلوم المعرفية في الصور لـابه المتتوعة الموجهة للطفل التي تربط بين الجانبين المعرفي والتربوي. - - - إسقاط الهوية الثقافية للسادرة على مضامين خطابها الموجه للطفل. - ارتكاز بعض الصور على معرفية مشتركة بين

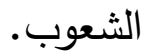
- مدى توفق الدراسة عند استخدام استراتيجيات تصويرية ذات صلة بالعلوم المعرفية، والقيم التربوية. تساؤلات البحث: - هل يحقق توظيف التراث في المجموعة موضوع

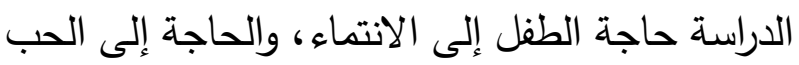

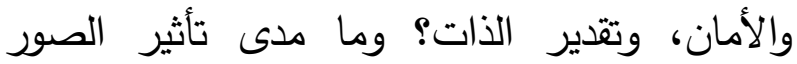
المعرفية في شخصيته؟ وما هي الإضافات الجمالية

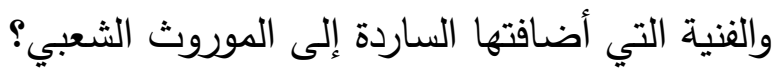
- إلى أي حد يمكن أن تغيّر الأنساق التصويرية أنماط النيا لفئي التفكير والسلوك لدى الطفل؟ - هل تعبر العلوم المعرفية عن القيم ذات الصلة بالتربية في المجموعة القصصية؟
المعرفة بصور تجسد القيم، ويكون الانتقال فيها من المجرد إلى المحسوس بما يتناسب وروح هذا التقدم؛ من الموروث الثعبي لبلاد ذات عوالم تصورية مختلفة تصور عوالم وبلادا أخرى ذات قيم وعادات وثقافة مختلفة عن قيمنا وعاداتتا وثقافتنا، وعن علاقتنا بأسرنا وتوجهاتنا وخصائصنا مما قد يجعل الطفل في حيرة نتغيا من المقاربة المعرفية للصورة في "مجموعة دنيا الحكايا" التعرف على الصور وطريقتها في تقريب الدلالة؛ لإقناع الطفل بمجموعة من القيم المعرفية والاجتماعية أو تتفيره من بعض السلوكيات المرفوضة، فهل استطاعت الساردة من خلال ذلك تعريف الأطفال بثقافات الشعوب وتزويدهم بالقيم؟ وما مدى مناسبتها لثقافتهم؛ للاعتبارات السابقة يهدف بحثنا إلى: - وصف الأنساق التصويرية المستخدمة بين الحقلين: المعرفي والتربوي، وما تحمله من قيم تستثر بشكل تدريجي، لتنغرس في صلب الفكر التربوي. - توضيح تنوع التطبيقات الممكنة للعلوم المعرفية في لتي تربية الطفل باعتبارها نظرية وممارسة. - تتبع القوة التأثيرية للعلوم المعرفية وما يمكن أن تئن تسهم به في تحقيق نقلة تربوية أكثر ذكاء، وأكثر تتاغما، وأكثر احتراما للقيم الأساسية.

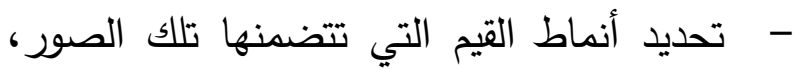
وأثرها في الإقناع بوصفها حجاجاً. 
التصويرية تعبيراً عن كينونة البشر وهويتهم، ويعتمد فيها الطفل على المشابهة في العملية التواصلية.

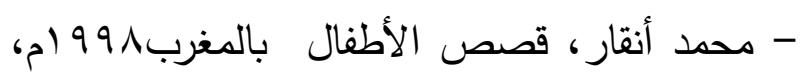
اهتم بتحليل الصورة القصصية في مختلف مكوناتها وسماتها النوعية والفنية والجمالية. وقد كان لنشر كتاب (الاستعارات التي نحيا

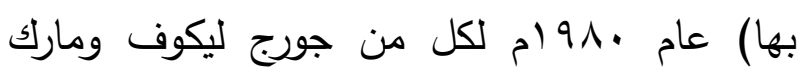
جونسون (Johnson et Lakoff)) الأثر الكبير في ملي مان انتشار النظرية المعرفية. وعلى الرغم من تقاطع دراستنا مع الدراسات السابقة

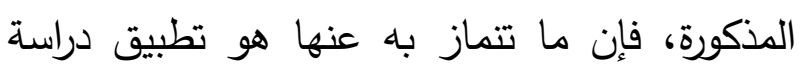
الصورة المعرفية على مجموعة قصصية للأطفال للوقوف على أهمية التصوير المعرفي في العملية

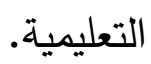

\section{الإطار المنهجي للاراسة:}

اعتمدنا في دراستتا هاته المجموعة القصصية "دنيا الحكايا" للقاصة فاطمة شرف الدين منطلقا؛ فقد هاتها اعتمدت القاصة على الحكايات الموروثة من بلاد مختلفة، تتناسب في بنائها العام مع الفئة المستهدفة

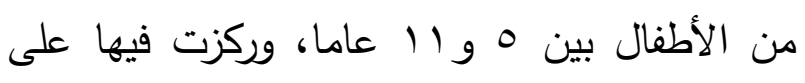

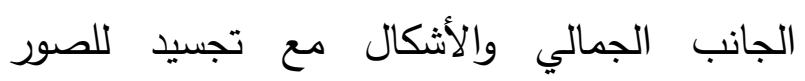

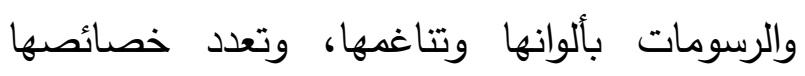
وسماتها؛ ليتفاعل الطفل مع الرسائل التي تحملها، وتهان وهذا ما قد يظهر في مجموعة من الأنساق: (أنساق التجارب والمعارف + أنساق لغوية -داخل الذهن-

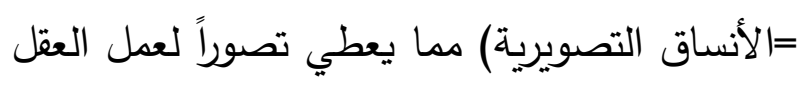

- كيف حافظت القصص على بعض الوضعيات المكتسبة من العلوم في القيخ؟ - كيف تسهم صور الخيال في التعرف على ثقافة الشعوب، باعتبارها من تقنيات الإقناع؟

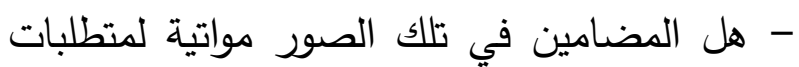
الطفل الذهنية واللغوية والنفسية والاجتماعية؟ هولئ -أيكون التعرف على المضامين والمعاني بالحجج

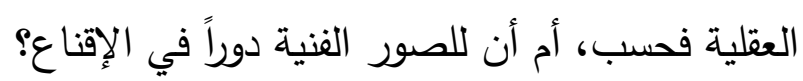
- أهمية البحث: تكمن أهمية البحث في: البه:

- الوقوف على آليات التصوير واستراتيجياته في

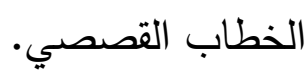
- إسهام التصوير في توضيح الأمور ومعرفتها بشكل

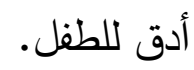
- الصورة في القصص من وسائل المعرفة والتواصل

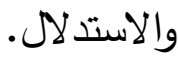
- الدراسات السابقة: - الانلات - عواطف جعفري، فطومة لحمادي، "البنية الاستعارية في النص الأدبي، مقاربة عرفانية

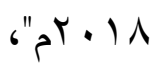

وهي دراسة تسعى إلى الوقوف على الاستعارات التصويرية، وقد خلصت إلى أن نظرية الاستعارة التصويرية هي نظرية من النظريات العرفانية. - عبد الإله سليم، بنيات المشابهة في اللغة العربية

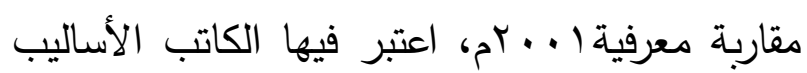


الإدراكي، باعتبارها أداة للفهم والتصوير ، ومن الصور

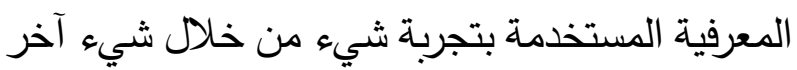
في تزويد الطفل بالمعرفة والتي تعينه على التفكير في المحتوى بطريقة تنظيمية تحكمها العلاقات بين المعلومات وطرق الحصول عليها (حسن، 1 (•r؟، . $(\leqslant 0$ وتتبنى اللسانيات المعرفية مجموعة من المبادئ المشتركة الموجهة، والمنظورات والافتراضات التي مدئ مدئ أفضت إلى مجال متنوع من النظريات المتداخلة

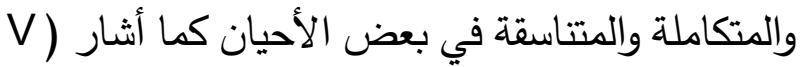
yvyan لدراسة كيفية نفاذ الفاعلين الاجتماعيين إلى لى لئل السياق في سياقات تواصلية محددة تعبر عن التيار المعرفي؛ تيار فكري ينهل من خمسة حقول معرفية؛

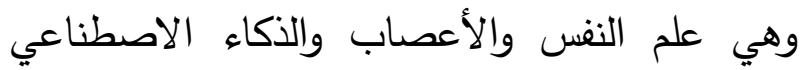

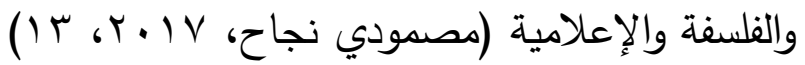
ويرتبط هذا التيار ارتباطاً وثيقاً بالدراسات التي تهتم

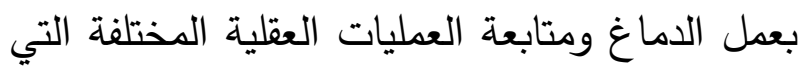
تتصل بالمعرفة الإنسانية والإدراك بشكل عام لبعل

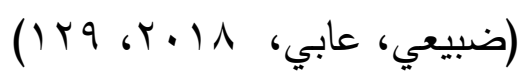

القييم: تمثل المعايير الاجتماعية ذات الصبغة التفاعلية العلمية، وتتصل بالمستويات الخلقية التي

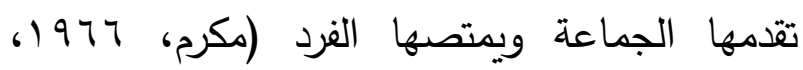
r YT)، ويرى الكثيرون أن التربية ظاهرة معقدة، ومتنوعة ثقافيا، وغير خالصة بالقدر الذي يمكن أن أن تكون بموجبه موضوعاً للمنهجية العلمية. غير أن

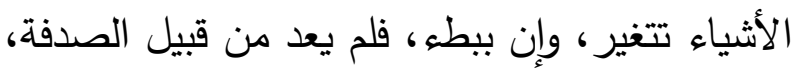

البشري في إدراك الأشياء والكيفية التي تتم بها وتسهح

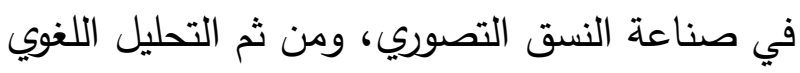
للألفاظ ودلالاتها في جميع القصص موضع الدراسة لمعرفة مدى الدقة في توظيف اللغة.

مفاهيم الاراسية:

التصوير: تعد الصورة إحدى وسائل الإيضاح الهامة في كل اللغات، وتعتبر البنية التصويرية من أهم الهن المباحث التي تميز البحث اللساني المعرفي، فجميع العمليات الذهنية بما فيها اللغوية تتم على مستوى البنية التصويرية، وهي جزء من الفكر (ضبيعي،

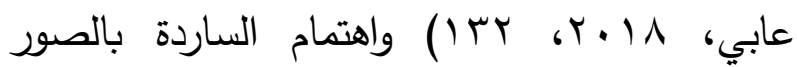
والرسوم ومحاولة تجسيمها في المجموعة القصصية نابع من إدراك أهميتها في الثرح والتوضيح، ولا يقتصر دورها على التزيين والتحسين (دحمان، الدران 9 1 • Y، TM ()؛ ولذلك م تتشكل الصورة من سياقات متعددة تنطلق لتعانق اللغة والمجتمع والعصر.

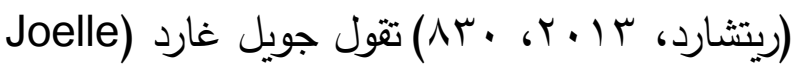
Gardes): "إن الصورة بمفهومها الوظيفي غير الزخرفي: "ليست منغلقة على ذاتها، فهي لا تجد

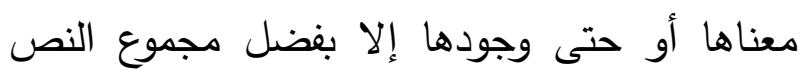
المرتبط بموقف معين، وباييتوس من ينتجها، وبباتوس ولها من يتلقاها" (Gardes, 2011, 181) ولعل لكلمة صورة أهمية خاصة لما تكتسبه من صيغة فنية، كما أنها من بين المفاهيم الرحبة التي تساعد على هن

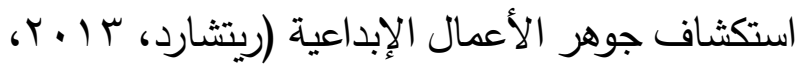

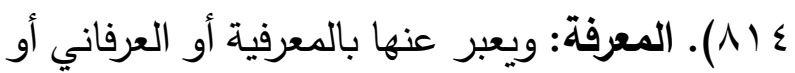


تقوم على ثنائيتي الخيال والواقع؛ الخيال باعتباره زاداً بما فيه من القيم والأخلاق والوعظ التربوي بصور باتئي شتى، والواقع الذي حمل الموروث من بلاد شتى، وهذا ما يؤكده مكسيم غوركي (Gorky Maxim) بقوله: "إن حكايات الشعوب تحتوي على نواة تعليمية غنية

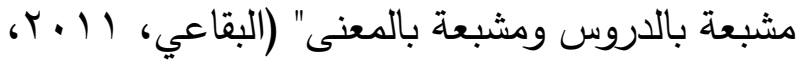

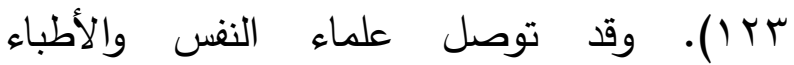
المتخصصون في الأعصاب إلى أنه "عندما نقرأ حكاية نفهمها جيدا، فإننا نخلق محاكاة ذهنية للأحداث الاعلى أنهاب

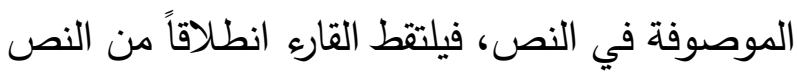
تفاصيل عن الأعمال والمشاعر للشخصيات ويدمجها في معرفة شخصية مستتدة إلى تجاربه الماضية، ويقع تسليم هذه المعطيات بعد ذلك إلى آلية المحاكاة

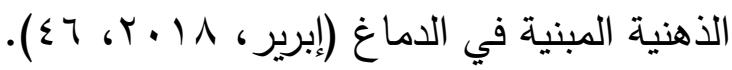
خطة البحث: جاءت الدراسة في مقدمة ومبحثين،

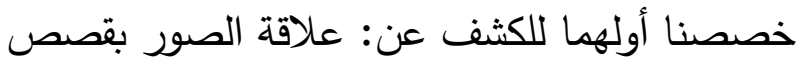
الأطفال، والتمثلات المشتركة للمعرفة في المجموعة القصصية المدروسة، وعلاقة العلوم المعرفية بدراسة

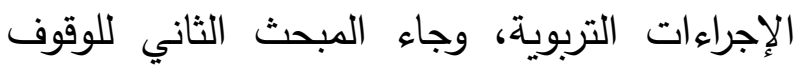
على: الدعائم التي تُبنى بها المناويل المعرفية في التصوير، وعلاقة الموروث التاريخي القصصي

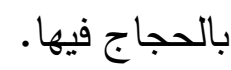

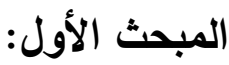
علاقة الصور بقصص الأطفال: اتخذت المعرفة في

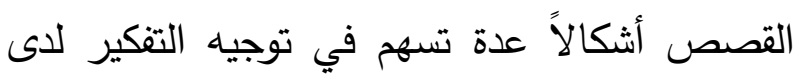
الطفل، ومن بينها التصوير موضوع الدراسة، وتستتد
أو حتى "الحظ من منزلة" المتخصص في المعرفية أن

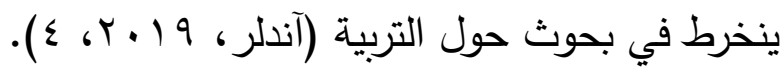
قصص الأطفال: القص في اللغة تتبع الأثر (ابن منظور، و99 1 (1) والقصة وسيلة من وسائل التعبير الفني النثري؛ وهي بذلك لوحة فنية جميلة تمتد على

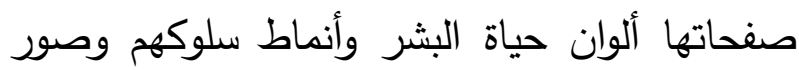

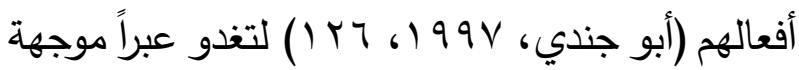

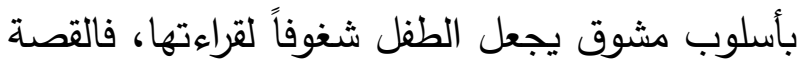
إذن، من مصادر إشباع رغبته في المعرفة ودافع في

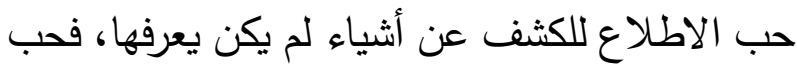
الاستطلاع، والميل إلى التعلم، ومحاولة الطفل في التعرف إلى جوانب الحياة المحيطة به، كلها تشكل دوافع إلى القراءة والإقبال على الكتاب، وأخذ الثقافة

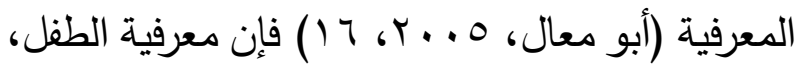
وتحديداً في مراحل تطورها الأولى تفهم من زاوية النمو، ومعرفيته موضوع للتفكير داخل مشهد نظري

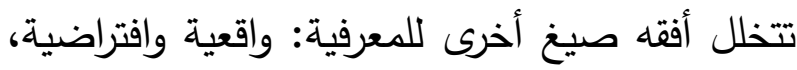
فالعلوم المعرفية تصوغ مفاهيم قادرة على احتواء مجموعة من الظواهر في إطار نظري موحد (آندلر،

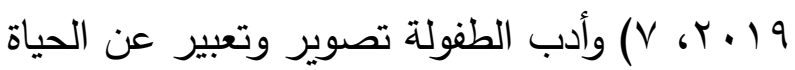
والفكر والوجدان من خلال أبنية لغوية، كما يعد أيضاً رسالة

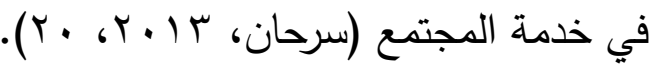
دنيا الحكايا: مجموعة قصصية من الموروث الشعبي

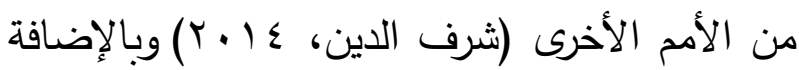
إلى كونها من وسائل التسلية المحبية للطفل، نجدها 
وفي هذا التمثيل البطولي (وسط ظهر التتين) تحقيق ثقافي لمبدأ التوسط، وهو التوسط الذي يشعره بالسيطرة

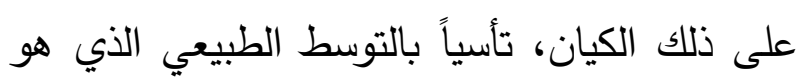

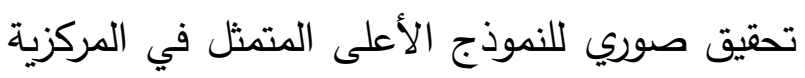

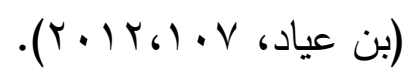

فالمعارف يجب أن تكون منظمة وفق نواة من المفاهيم المفاتيح، ومن اللازم دعم تنكير الطفل حول سيرورات

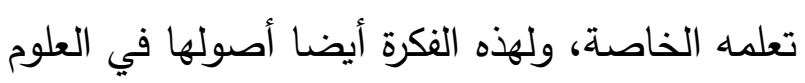

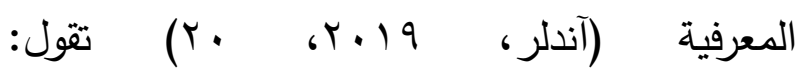

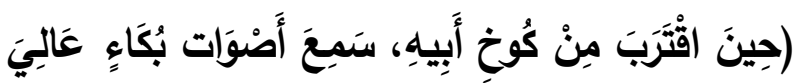

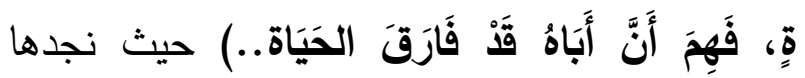
عوضت عبارة (مات أبوه) بعلامات لذلك (بنكراد،

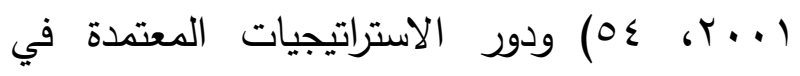
معالجة الخطاب القصصي ذهنياً، من شأنها تسليط الضوء على كيفية بناء السياق لدى الساردة في توجيه تلك المعارف من تراث الثعوب إلى الطفل ودورها في صناعة التمثلات وتعديها أو تغييرها بإعادة التنسيق

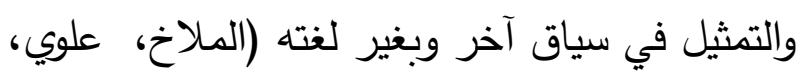

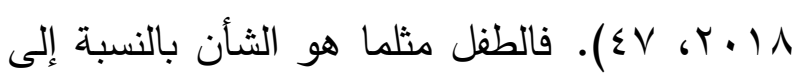
الراشد في مرحلة محددة من فهمه للمعارف بطارية مفاهيم ينبغي عليه التخلي عنها لبلوغ فهم جديد

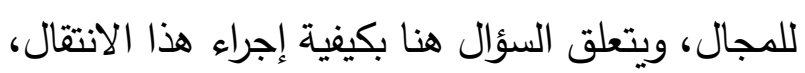

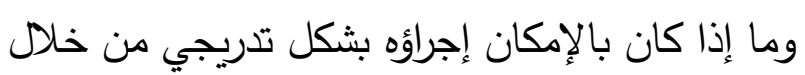

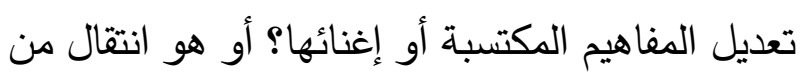

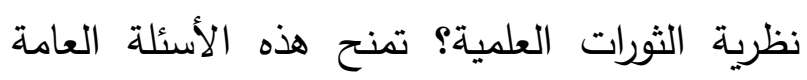

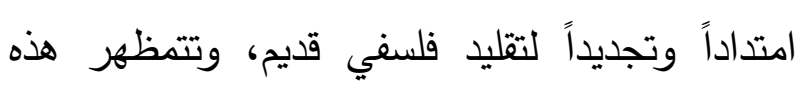

قراءة الصورة فيها على ثقافة المتلقي ومعرفته بالعالم،

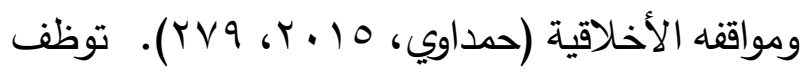

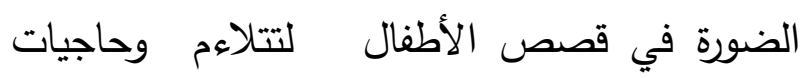
الطفل العقلية والنفسية، فنتشكل بذلك أساس العلاقة بين الدال والمدلول من مجموعة العناصر اللغوية

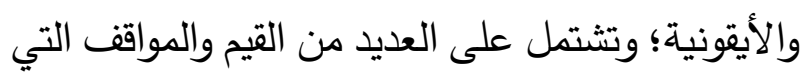
تبرز أشكال التواصل التي تؤثر في سلوكياته وتنشئته، بالإضافة إلى توسيع خياله باتجاه الأفق الرحب، كونها لتولئ عناصر محببة للطفل، تقوم على تحفيز إدراكه لمغزى بلى باتهاه القصص فتتري خياله (زلط، 9991، 19 (1) وتترجم الانطباعات والانفعالات إلى أشكال أدبية بطريقة سهلة

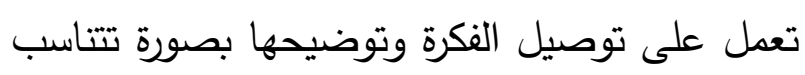

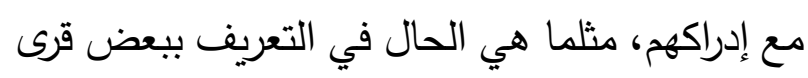

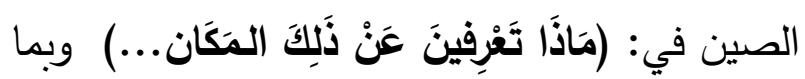
أن من يكتب للأطفال يلجأ إلى سبل تحريك التصورات القبلية بقصد تطويرها في العديد من السياقات

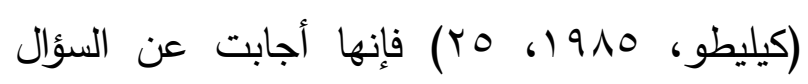
بصورة مبسطة بوصف الحدائق والأنهار وهو وصف الهابت يدركه الأطفال؛ لأنهم مجهزون بتصورات قبط بـلية،

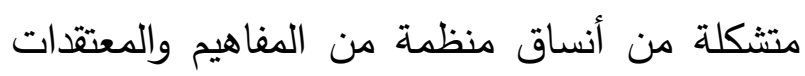

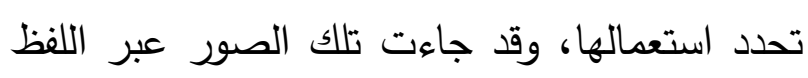
والرسم ومن ذلك قولها في سياق آخر تصف فيه مشهدا بطوليا: (قَفَز قَفْزَةً عاليةً وَحَطَّ عَلَى وَسَطِط

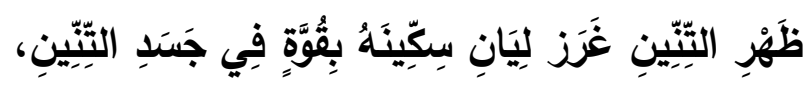

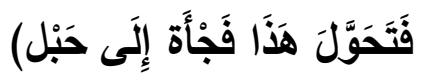


1999 1، • (1) في ظل هذا الاتجاه جرى توسيع مجال

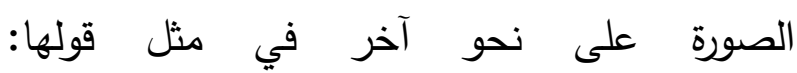

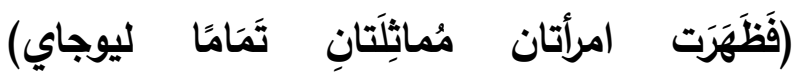
والمتثابهات يمثلن المماثلة في المجال أو الحقل الواحد في التشبيه الذي عبرت عنه، وتتبنى استراتيجية

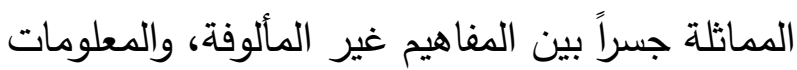
السابقة للطفل؛ تساعده على تكوين بنية معرفية جديدة

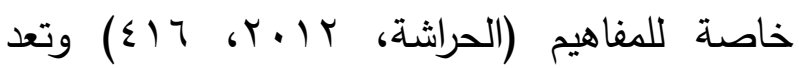
المماثلة مصدرا يمكن الطفل من فهم المفاهيم العلمية واكتسابها، وتعمل على تتشيط القدرات الإبداعية والعقلية، وتهيء الفرص لاكتساب المهارات المعرفية، Lawson, وهذا ما يطور بدوره مهارات التفكير لديه

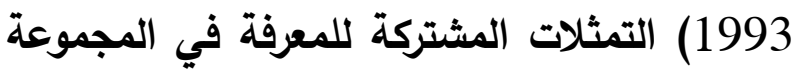
القصصية: الخطاب القصصي نتاج الذهن يشكله ويتشكل به؛ لتعكس لنا التمثيلات الجماعية المشتركة التي تتحكم في إنتاج الخطاب وتأويله ( الملاخ،

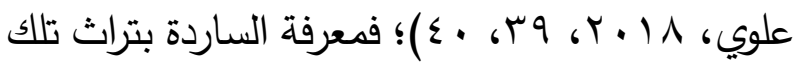
المجتمعات وكون الرحلة دائمة أمر معزو إلى التأسيس

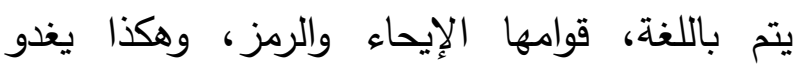

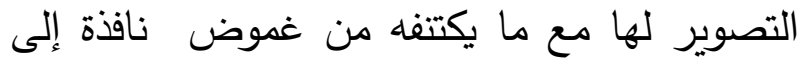

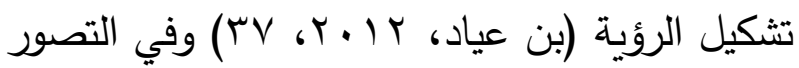
للحياة رحلة نجد أن: الحياة: قد تكون لها وجهة معينة

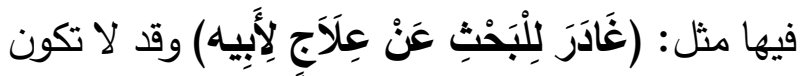

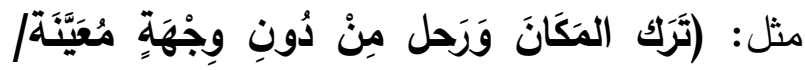

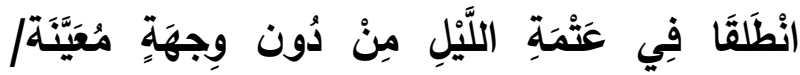

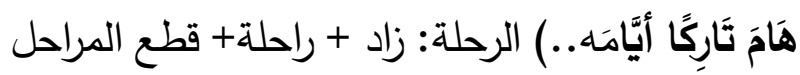

الأسئلة في شكل سلسلة من الأسئلة الخاصة ذات

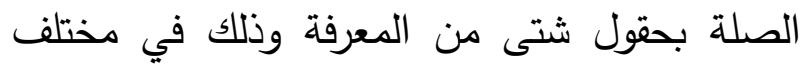

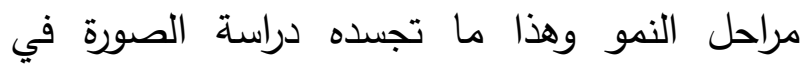

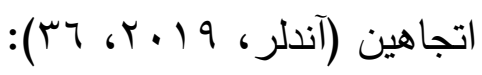

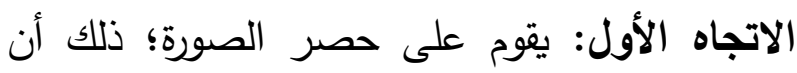
إيضاح المعنى بالصور هو أصيل في الفكر الإنساني وفي قولبة صور العوالم والأشياء المحيطة بالطفل وتكيف تفاعله معها (نعيم، 919 (، 1) (1) ولو توقفناء

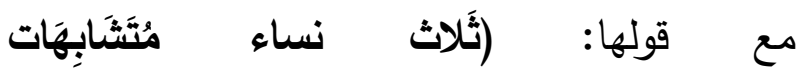

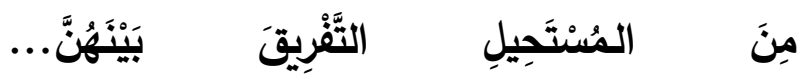
إِقَتَرَبَ لِيَتَمَقَّن فِي وُجُوهِهِنِ، فَلَلَحَظَ

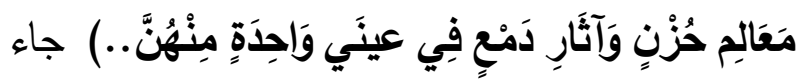
فيه التصور بين المماثلة والتقريق بحسب المجي لمال، ويشترط الإدراك كما هو معروف حضور الموضوع الممثل ما يمثل أمام أنظار الرائي بشكل مباشر ففي غياب هذا الثيء ستتنفي شروط التعرف على الأشياء الخارجية، فلا يمكن أبداً أن نتحدث عن إدراك إلا من خلا الحصر والإمساك بنسخة متحققة من موضوع إنهان مرئي، ونجد أن ذلك يدل في التمثيلية الذهنية التي هري

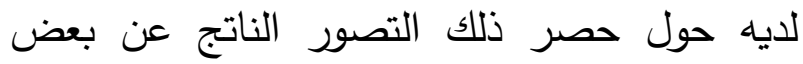
الخصائص المستمدة من المحمول للشكل الخارجي

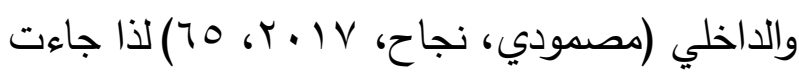

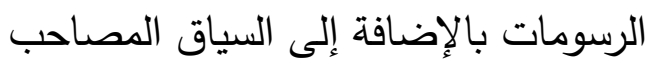
لاستكمال شروط التعرف لكي توضح تلك الرؤية. الاتجاه الثاني: في دراستها توسع في فهم مكوناتها إلى حد أصبح يشمل كل الأدوات التعبيرية (الولي، 
المعرفية التي يكتشفها الدارس بتحليل الاستعارات والنماذج الذهنية ذات السيرورة التاريخية المنغرسة في تربية ثقافية جماعية ( الملاخ، علوي، 1 1 ـ ب، جس-

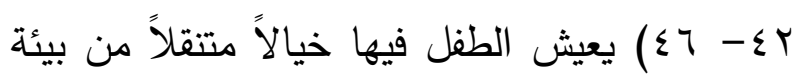
إلى أخرى، حيث تقوم القصص على منطق القياس بالتمثيل حتى يكون الاهتداء إلى فهم غير المعروف من خلال المعروف والقديم، وتتفاعل التجربة العقلية والجسدية تفاعلاً تسوغه التجربة الحسية والعقلية والفطرية بداية بتصوير بالرحلة

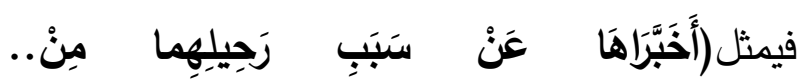

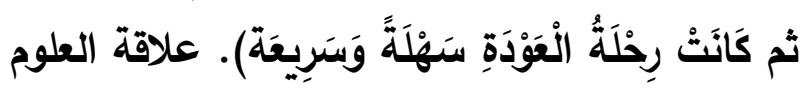
المعرفية بدراسة الإجراءات التربوية: للعلوم المعرفية علاقة وثيقة بالإجراءات التربوية التي يقوم فيها التصوير على تحديد المراد من التخاطب في الحياة اليومية، كونه ضرورياً في عمليات التعلم التي يحتاجها الطفل؛ إذ استثرت الساردة آليات التصوير في الربط

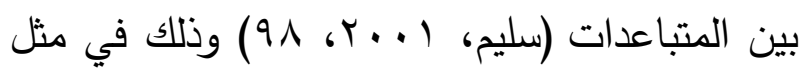
قولها: (فِي يَوْم سَمع هيروشي شِيرُو

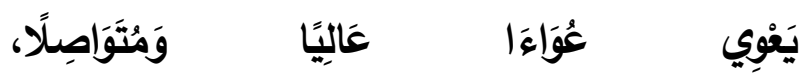
اسنتَغْرَبَ ذَلَكِ فَخَرَجَ لِيَرَى مَا فِي الأَمْرِ، وَجَدَ شِيرُو يحفر التُرَّابَ

بقَقوَائمِهِهِ بِحَمَاسِِ كَبِير .. فَحَصَلَ عَلَى قَطْعَة لَحْمِ دسِمِةٍ مُكَافَأَةً عَلَى إيجاد الْكَنْز ..) فلفظة (يعوي) في ذاتها متعددة السمات ولا تتخلص من كثافتها إلا في السياق المصاحب، وتنشيطه للسمات المنسجمة من الكلمات المجاورة، والأمر لا يتعلق هاهنا بتنشيط سمة
+ اكتشاف المجهول+ مليئة بالأخطار + التوجه نحو الهدف، أو التوجه بدون هدف. بالمطابقة: الجمع بين الحياة والرحلة في (اكتشاف المجهول - التوجه نحو الهدف). بالمماثلة: (قطع المراحل - التقدم في العمر) بالتشابه (عدم التجربة + الزاد + الرحلة) وهكذا تظل البنيات التصويرية مرتبطة في تشكلها بتمثيل الرحلة بواسطة آليات معرفية تعكس اللغة مظهرها الدلالي جزئياً، ويؤكد هذا أن التمثيل والتصوير للعلم والحياة ملكة معرفية راسخة في الذهن، مقترنة بالتصنيف المتجدد للخطاب في صياغات تصويرية متواضع عليها تتقاسمها مجموعة اجتماعية معينة؛ فمن خلال التصور بأن المعنى للرحلة ينبثق من الترابط التراكمي للأطر والاستعارات التي تسهم في إنتاج المعنى وفهمه (فضل، 99V ( ، 0 0)، وبالوقوف بداية مع رحلة الصورة الذهنية والبصرية في دراسة كل قصة وما تشير إليه من معان متعددة نجد لكل منها علامة معرفية، تدور حولها أحداث الرحلة نتلمسها بداية من عنوان كل قصة ومنه في جميع صفحاتها، اليابان: الكرز + الآلة وتمثلها المطحنة/ الصين: ورقة القيقيب+ التنين/ السكليت: القيثارة +الطبيعة/ البرازيل: الصندوق الذي يمثل الاستعمار + البشرة السمراء، وفي إطار النماذج المعرفية والذهنية الخاصة، ربط بين البعد المعرفي والبعد التاريخي والثقافي وهو ما فتىء فان دايك يثدد عليه لتطوير معالجة مندمجة (Van Dijk) للخطاب تستدمج البعدين التاريخي والثقافي في الأبنية 
توجد عادة بين اللغات، فلا تقود غالبا إلا إلى استتناجات نسبية.

النهج: تدين بهذه المعارف بنتائجها المنهجية، من معناها الأكثر اتساعا، الذي يمكن من خلاله

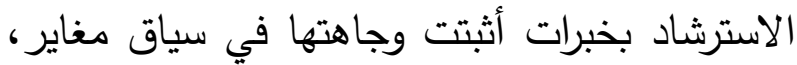
ولكن من المهم أن نشير إلى أن العلوم المعرفية يمكن

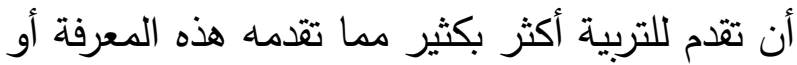

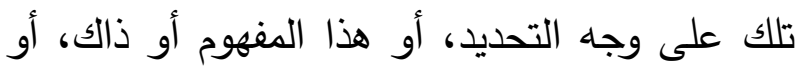

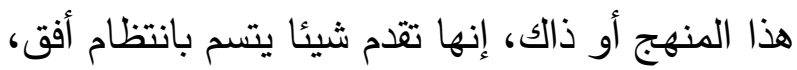

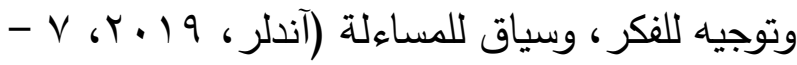
צY) فإن المفاهيم هي منشآت تنشئها عمليات المعرفة التي يتمتع بها الإنسان، وهي عمليات تساعد على الهي تصنيف الأثياء عن طريق التجريد المنظم وبعبارة أخرى فالمفهوم ليس صيغة تجريدية نستعيض لهاء لهائ لهني المحسوس فحسب بل هي طريقة في شكلنة المعنى المحسوس وصياغة حدوده (بنكراد، .... r، 9) وهو ما نجده في أن سعي الساردة القصصي نحو إماطة زيف الحقائق والكثف عن متناقضاتها جعلها تبحث في الوقائع عن التناقضات لبعض ولفئ السلوكيات في مثل: الجار الحسود والجار الطيب/ العطاء والمنع.. لتكثف عن المفارقات الكبيرة والتتاقضات بين الجارين، ويمثل ذلك تصوير الجار وهو يراقب جاره وما ذالك إلا لتقبيح الفعل وفاعله، بغرض استمالة عواطف الطفل كي يدرك مدى بشاعة تلك الخصلة، وتنفره منها

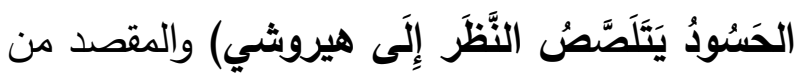

(الحيوان)؛ بل يتعلق بتنشيط السمة الخاصة التي تتحقق بتنشيط الفعل يعوي لسمة الضجيج المتواصل الذي يتكرر، وبالتحول من التصور النمطي إلى التصور اللساني الذي يمكنه تقليص الأدوار المحورية لتحقيق صلاحية مؤشر مرتفعة تُكن الطفل من الطن التعلم، فالطفل يعتمد على التصوير الذي يكثف الربط بين المتباعدات، بمعرفة إثارة العواء إلى تحمس الكلب، ومن خلال تبني التصور المعرفي تصوراً تفاعلياً يذهب إلى أن الصور بكافة أشكالها عملية فكرية وليست لغوية فقط يجد فيها الطفل سندا معرفيا لتوسيع الجملة بحيث تصبح: (شيرو المخلص يعوي

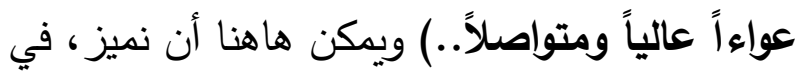
مرحلة أولى، بين ثلاثة أنواع من الإسهامات (وقائع)

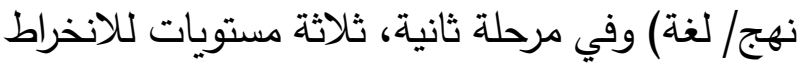

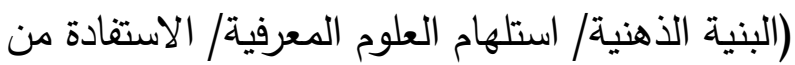
النظريات المنحدرة من العلوم المعرفية). المستوى الأول: الإسهام: وبرز في ثلاثة أنواع: الوقائع: تقدم العلوم المعرفية وتبدو صلتها بالتربية واضحة، قد تكون سلبية وأحيانا أخرى معلومات تسمح ونبات بإحراز تقدم، في مجال التعليم، وبشكل أوسع في

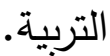
اللغة: حيث تتوارى هذه المعارف خلف مفردات مما يمنح إمكانات مفهومية جديدة لمن يبحث في التربية، يتجاوز حتى ما يمكن للعلوم المعرفية أن تقوله، إن ما يوضع على المحك هو دائما الاختلافات الدلالية بين اللغات، أما الاختلافات الصوتية، التي 
تجاه الظروف الاجتماعية، خاصة تلك العلاقة بين الجار وجاره/ وصف المتلصص بالحسود. المستوى الثاني للانخراط: ويتمثل في ثلاثة مستويات للانخراط (البنية الذهنية/ استلهام العلوم المعرفية/ الاستفادة من النظريات المنحدرة من العلوم المعرفية) -البنية الأهنية:يشتمل نطاق الانخراط الأدنى على الأى الفكرة التي تبدو مأمونة، مفادها أن الفاعلين في السيرورة التربوية (تلاميذ، وبشكل أعم "المتعلمين" والأساتذة، بل والآباء، والفاعلين الآخرين) مزودون ببنيات ذهنية خاصة تشرط هذه السيرورة وتبدو مأمونة بسبب عموميتها الكبيرة. - استلهام العلوم المعرفية دون اقتراض مباشر منها: يتميز هذا المستوى من الانخراط بتطبيق المنهجيات

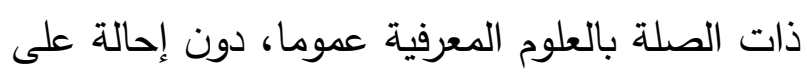
هذا العمل أو ذاك من أعمالها، حيث يتم إنتاج فرضيات دقيقة تمليها أسئلة مستوحاة مباشرة من هن الوضعية التربويـة.

-الاستفادة من النظريات المنحدرة من العلوم المعرفية: سوف نفهم بشكل أفضل المستوى الثاني لانخراط العلوم المعرفية من خلال مقارنته بالمستوى الثالث، وتكمن ميزة هذا المستوى في تقعيله للنظريات والنتائج المحصلة في العلوم المعرفية. ينبغي التمييز بين نمطين من التطبيق، بحسب ما باستطاعة العلوم

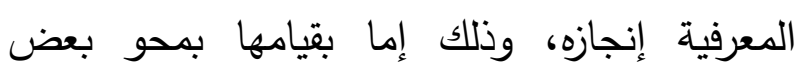
الأخطاء أو بتقديمها فرضيات ومعطيات جديدة،
إطلاق التلصص جعل الصورة ذات دلالة مرئية لأصوات اللفظ، بالإضافة إلى الرسم في الصفحة المقابلة؛ فالتلصص أضحى ذا وجود إمكاني وذا كيان لما دخلت أداة التشبيه في حيز الفعل ولما قالت

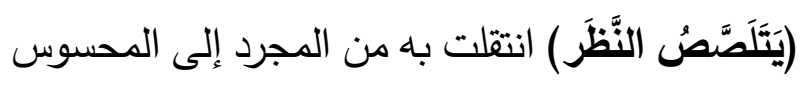
ودخلت به في عدة مركبات: التجريب: فعل النظر إلى الجار المجرد/ الزمني: إذ تم النظر في زمن انقضى/ المكاني: ما هو داخل الحد البصري في الجوار/ الحالي: في وصف النظر بالتلصص.. حيث تسعى إلى إثارة مشاعر الطفل برسم تلصص الجار الحسود لجاره، والغضب عندما يرى جاره ينعم بأي شيء، ليسهم في بيان الصورة ورود أداة التشبيه بصيغة (الفعل) يتلصص من لصص، والاسم اللص والأصل اللغوي لكلمة اللص هو التقارب والالتصاق، فهو المتقارب الأضراس (الجوهري، 999 (م) وهو فعل يماثل فعل السارق الذي يسرق ممتلكات الآخرين، فيحاول إخفاء ما يقوم به، وكأنه يقارب ما بين كفيه ومنكبيه، فالمعنى يدور على الأخذ من الغير بغير حق، وعند الزمخشري يتلصص: إذا تكررت سرقته

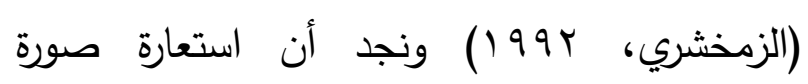
(التلصص) لفعل الحسود بإسقاط السمات الإيجابية على ما يحصل عليه الجار الطيب، والسمات السلبية على ما يحصل الجار الحسود/وفي اختزال الحوار للصراع بين رمزين متناقضين؛ لذا استعملت سلوكيات رمزيـة من أجل تصوير موقفهما 
الذهنية/ والرماد: بقايا المعرفة/ ونثر الرماد: توزيعها

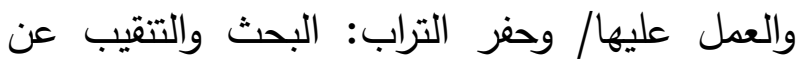
المعرفة/ والبذور : التكوين/ والجذور : الحياة الفكرية) فالثمار كما في نظرية المعرفة تختلف عن الأثجار

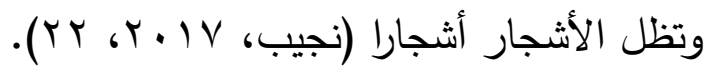
الاستفادة من النظريات: حيث يمكن لكل واحد أن يصطدم بالآخر ، وحيث يمكن لكل الآذان أن تتلقف كل جديد إلخ. إنه أكثر شبها بنظام مجزأ على نطاق واسع. يكتسي التعرف على "قالبية" هذا "المعمار" (الدصطلحان تقنيان ومجازيان في الوقت نفسه) أهمية بالنسبة إلى المرسل، مثل الأهمية التي يكتسيها تحديد التيدية

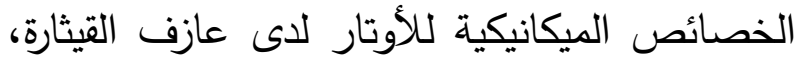

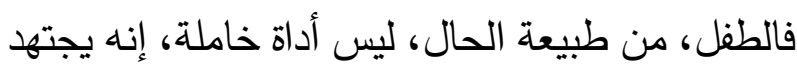
في إصدار حكم وبمقدوره أن يعيد تنظيم معارفه بشكل عفوي، وأن يربط بصلة قطاعات مختلفة، ويطرح أسئلة، وينشئ فرضيات ثم يبحث عن إثباتها. لكن هذه

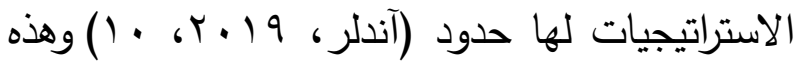
الظواهر معلومة عند البعض فهي تنتح حقلا واسعا للتنكير في أسس المعرفية. وبشكل خاص في سيرورة الكَقْوَلة وفي طبيعة الذاكرة وفي مفهوم القاعدة وفي التحول التصوري... لكن رغم ذلك توجد أدبيات متخصصة في الفروقات بين معلم مبتدئ ومعلم حاذق، وفي وسائل تحقيق الانتقال من مرحلة المبتدئ إلى مرحلة الحاذق في أحسن الشروط (آندلر، 9 1. T)،

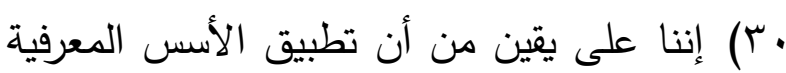

سأقدم مثالاً يعكس أهمية الصورة في العلمية يتمثل في: الآلّة في قصة شجرة الكرز من اليابان:

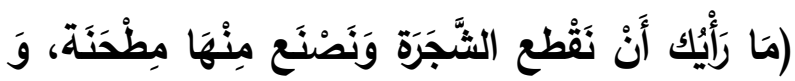

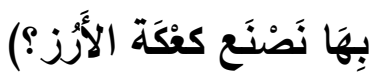
في البنية الذهنية: يتعلق الانخراط بصيخ الانقال من النقال

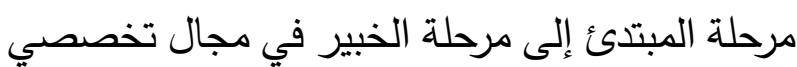
لا يحدث بين اللحظة التي بدأ فيها التعلم، مثلاً

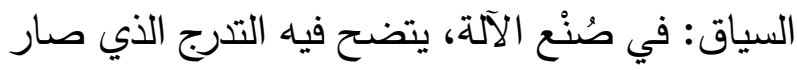

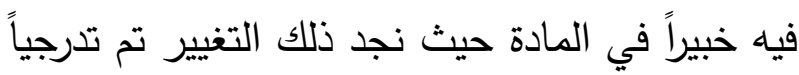
باكتساب معارف إضافية وبتحسين الإنجاز . وفي استلهام العلوم المعرفية فالآلة المتمثلة في التهاري المطحنة تقتضي ما يدخل لها (من تقطيح الثجر ) وما يخرج منها من منتجات (الكعكة) يقابلها تماماً الذهن وما يدخل فيه (من معرفة) وما يخرج منه (فكرة) حيث ليث نرى في تعبير الساردة عن تلك المعرفة فعلاً تراكمياً يتحقق بتجميع تفاصيل الواقع المادي مع فاعلية العقل وإبداعه وظروف الإدراك والأفكار في:

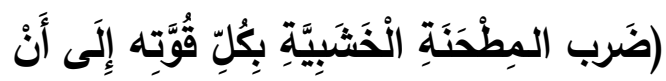

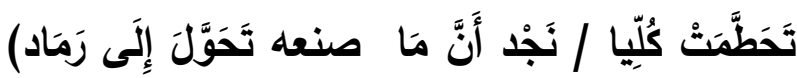
ليمثل نثر بعض الرماد حول أشجار الكرز التي فقدت التها

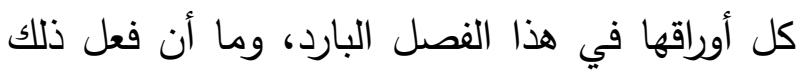
حتى نبتت أوراق على كل الأشجار وصارت تزهر بكثرة وتحمل ثمر الكرز، حيث تمثل (الثجرة: المعرفة/ والمطحنة (الآلة): الذهن/ وكعكة الأرز (منتوجات الآلة): الأفكار/ وتحطيم الآلة: معرفتها 
، and Fisch, 1744

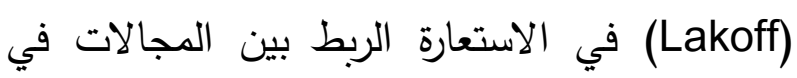

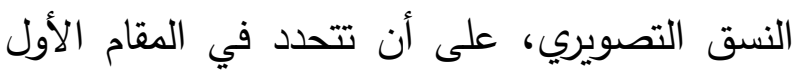

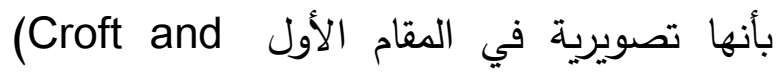
Cruse,196-197) وفيها يتم استعاضة: (المشبه والمشبه باه ووجه الشبه) بمثلث أوسع يحتوي على: (المجال المصدر والمجال الهدف والتناظرات)

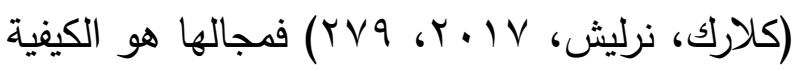

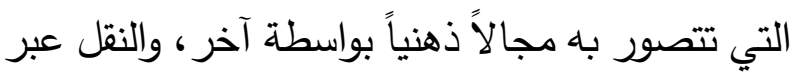

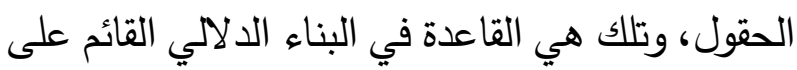
التناظر بين المجالات في النسق التصوري (الكراري،

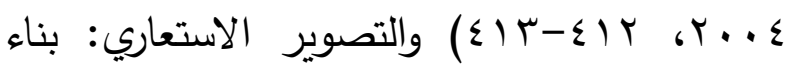

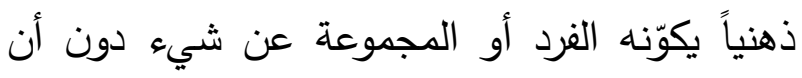

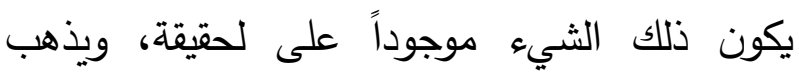
لايكوف وجونسون إلى أن التصور الاستعاري هو دونى

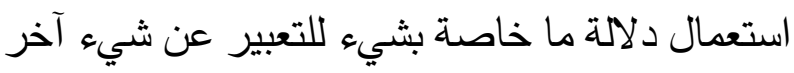

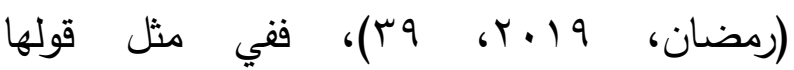

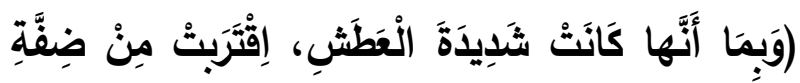

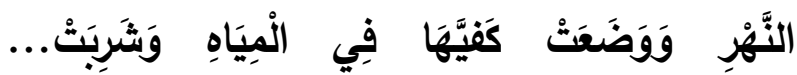

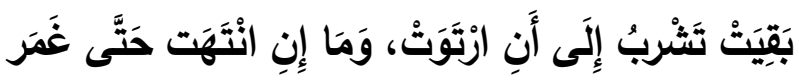

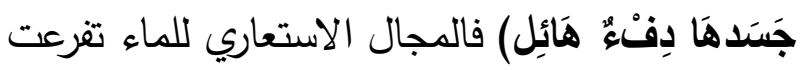

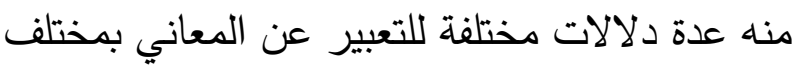
مناحي الحياة تتضح في الأفعال (شربت، ارتوت،

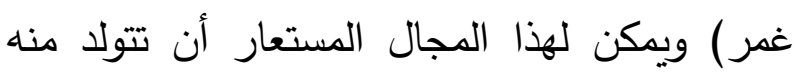
ألفاظاً مضادة لكنها لا تخرج من دائرته الاستعارية

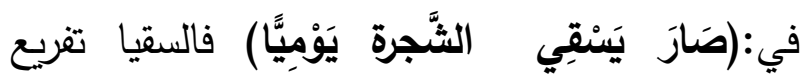

في المقام التربوي يعضد استراتيجيات العملية

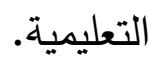
المبحث الثاني: أولاً: الدعائم التي ثُبنى بها المناويل المعرفية في التصوير: تتمثل هذه الدعائم في: عدة نظريات منها: الاستعارة المفهومية/ الجسدنة/ الخطاطة/ الذهن. 1-نظرية الاستعارة المفهومية: عرف ريتشاردز (Richards) مختلفتين تعملان معاً وتستتدان إلى كلمة أو عبارة الهارة يكون حاصل معناها ناتجاً عن تفاعل هاتين الفكرتين (فضل، ب991 19، 10 (1) وتستخدم الاستعارة المفهومية لبناء المفاهيم المجردة وفهمها عن طريق مفاهيم أكثر

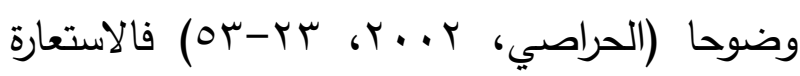
ليست إضافة لا قيمة لها؛ بل هي جزء من نسيج الخطاب التعبيري تقوي دلالته وتعمل على تعميقها في نفس الطفل لتسهم في الإقناع بترسيخ بعض القيم كما تدفعه إلى تغيير قناعاته في موضوعات مختلفة، يتحدد مفهومها في أنها التحدث عن الأشياء بالطريقة التي تُرك فيها الأشياء، التي تُشهم في تشكلها الثقافة والتجربة، وتستتد على اللسانيات المعرفية الإدراكية بمعنى: "أنه يتم إنتاج تعبير معين عن طعيتئ طريق تصور لموقف معين، ومن أهم الدراسات المعرفية للاستعارة دراسة جونسون ولايكوف في قولهما إن الاستعارات يمكن أن تختلف من ثقافة إلى أخرى، لكنهما يدافعان

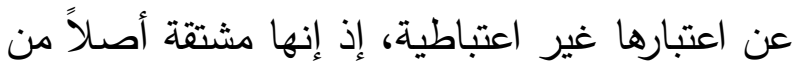
تجربتا المحسوسة والثقافية والاجتماعية Bergin) 
الجمالي والتخيلي وماله من أهية في الإقناع كان وسيلتها على ذلك.

-العلاقة: مفهوم يتعلق بالإدراك العلائقي، ويظهر التتريب في صور مختلفة منها: (هَلْ بِإِكَكَنِيّ أَنَّ

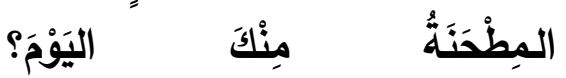
أَسْنَّعِيرَ

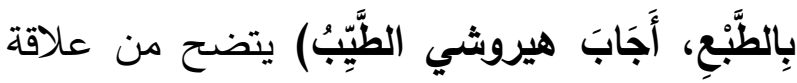
المعير بالمستعير، ولا يقع هذا إلا بين طرفين متعارفين، ويوضح ابن الأثير هذه العلاقة بقوله: "المشاركة بين اللفظين في نقل المعنى في الاستعارة من أحدهما إلى الآخر كالمعرفة بين الشخصين فين في لإني نقل الثيء المستعار من أحدهما إلى الآخر (ابن الهن

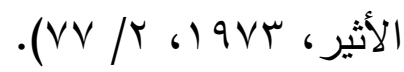
-التصوير : يسهم كل ذلك في عرض الأشياء وكأنها

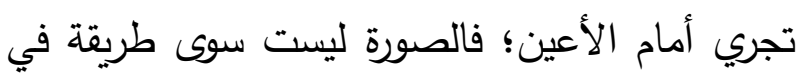
وصف الأحداث على نحو يجعلها حاضرة في وعينا

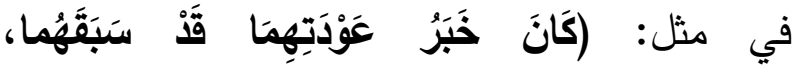

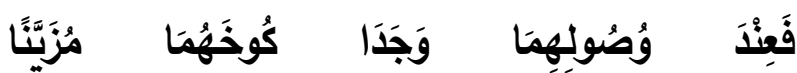

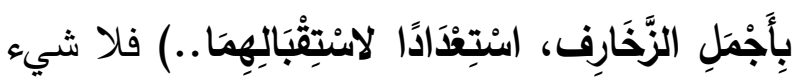

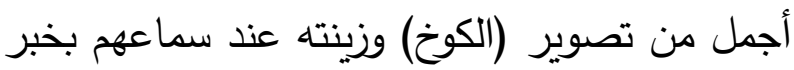

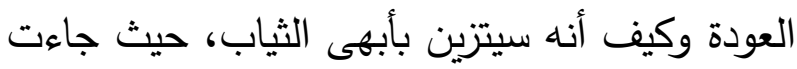

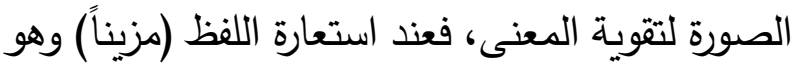
أمر محسوس تختص به العروس؛ لتظهر بأجمل

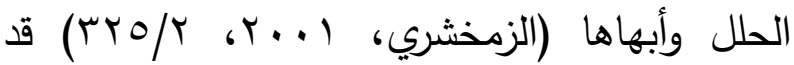
يصور ذلك لعقل الطفل الهيئة التي سيظهر عليها

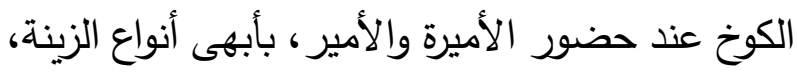

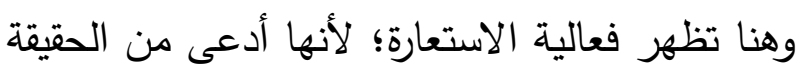

استعاري مضاد للعطش، وقد تغدو كذلك من الأفعال

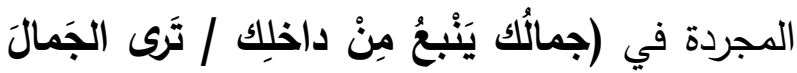
يَطْفو) والاستعارة المعرفية بهذه الدلالة الإدراكية ليست مرتبطة بتزيين الأسلوب وتجميله، إنما ظاهرة ذهنية تصويرية وآلية في التنكير ، حاضرة في مجالات حياتتا اليومية ومؤسسة لجانب كبير من الأنظمة التصويرية

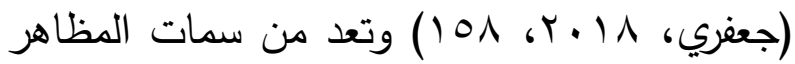
البلاغية التي تستطيع أن ترقى إلى مستوى التصوير اللغوي، ومن هذا المنطلق كانت لدينا عدة آليات

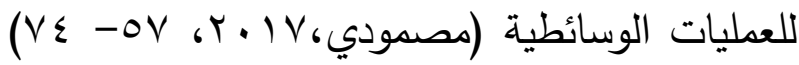
ومن الآليات التي اقترحتها الدراسات النفسية لفك لغز الاستعارة: - الإن -المشابهة: وتستند إلى جملة العناصر المشتركة من المعارها خلا الصور التي تجسد اختيار الألفاظ وفقاً للمعطيات، التي تجسد حضورها في الوعي وتمثيلها في التلقي ومن هذه الصور المحاكاة الصوتية ووجوه

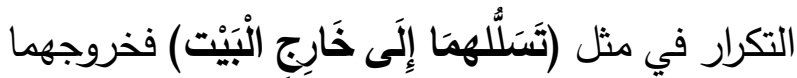
خفية والتسلل؛ أي تكلف الانسلال يصورهما بإبرة الخياطة في انسلالها في ذلك النسيج للخروج منه... وتختلف عن هذه الصورة السلبية عن صورة إيجابية

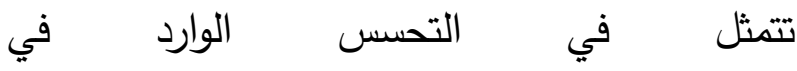

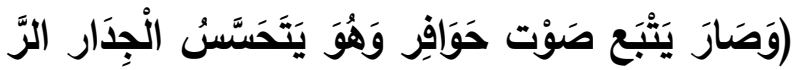

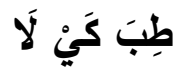
يَتَعََّّر) لنجد أن الصورة تهدف إلى البحث عن الدليل والإثبات للادعاء أو الاعتراض، ليندا لهورة البعد البعد 
إلى الآخر ، ويلاحظ أن هناك عدداً كبيراً من المحددات الضميرية المقرونة بالضمائر المنظمة بحسب التقابل،

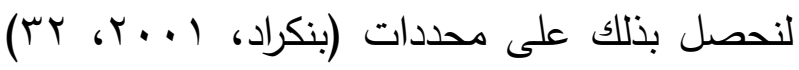
والغرض من ذلك هو اختزال المسافة في كثف لهف الأصل، لتلتحم مع عناصر رسم (الأرنبة والأميرة والعملاق) وتكون بمثابة علامات معرفية تبرز الفروق

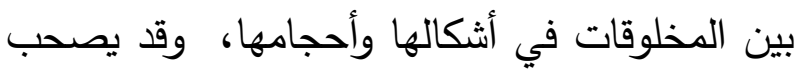

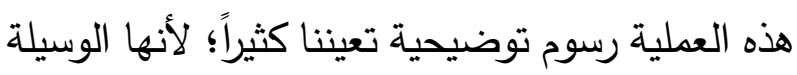
التي يمكن فهم كثير من الصور من خلالها على مقدرة الطفل على إدراك الأشياء وطبيعة قدرته العقلية فوظفت هذه القدرة الإدراكية من خلال الصور المعلومة في تقديم الصور الدجهولة، بالتصور الذي نتبناه عن الثيء هو الذي سيحدد كيفية سلوكنا

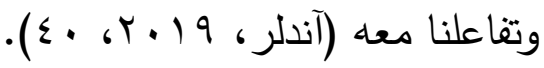
-الاتجاهية: وفي هذا الإطار كان الاهتمام بدراسة

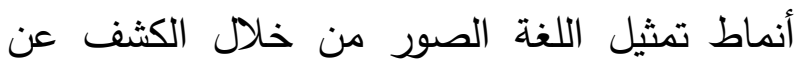
التصورات الهندسية المتعلقة بالمكان واتضاح أنماط الأبنية ويتأسس على مفهوم الصورة والخلفية الذي لتي ينتمي إلى حقل علم النفس من خلال مفهوم الصورة وفي هذه الحالة يمكن للكيان الخلفية أن يتخذ تشكلات خطاطية متعددة يمكن دراستها من خلاه زاويتين

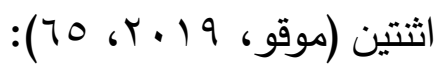

أ- - إنه يمثل هدفاً للمسار المنطلق من الصورة: وتتحقق وظيفة الظرف في إيصال الصورة إلى الخلفية

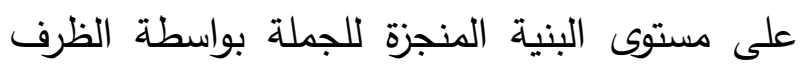

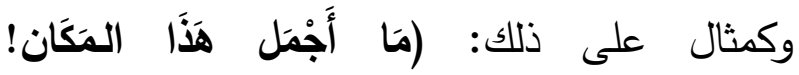

لتحريك همة الطفل، وتوجيهه ما أمكن، ومورد هذه التصوير هو الخطاب جارياً على المضامين المعرفية، ليوفر للمتكلم المعرفن أنماط في التعبير مختلفة لاختلاف زوايا التتاول الذهني لتلك المضامين (زايدي،

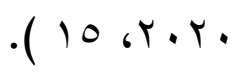
-الاندماج: للتصوير وتيسير الاندماج في الحياة الاجتماعية بُنيت العديد من الأنساق المعرفية الإدراكية

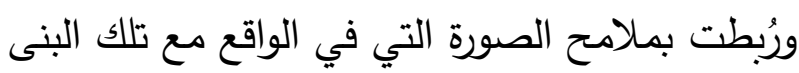
التصويرية في الذهن لرؤية الثيء الملتبس، بربط

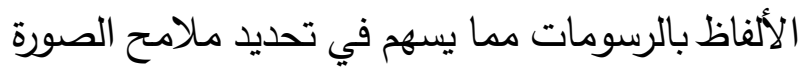
المختارة سواء كانت (فتاة/ أو أرنب/ أو عملاق) ليكون ذلك بمثابة حكمنا على الصورة الملتبسة. إن الرؤية التصويرية للعالم بتصور ذهني للعوالم الطبيعية والاجتماعية والنفسية، من خلال موقف أو حالة نفسية تستدعي إقامة علاقة بين هذه العوالم، ووضع خطة ملاهن

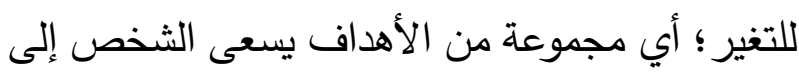

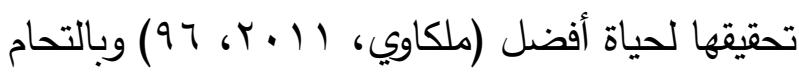

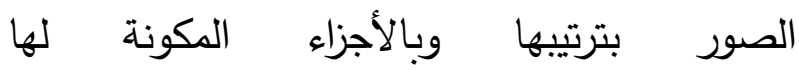

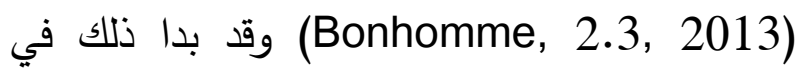

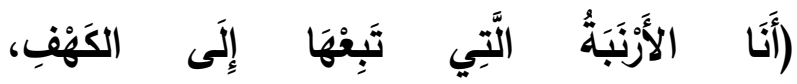

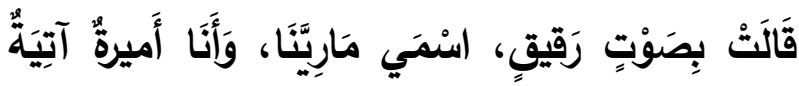
مِنْ بِلَادٍ

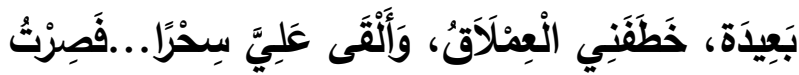

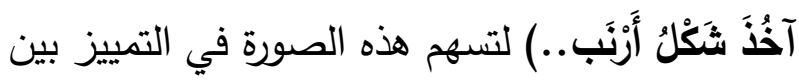
عالم الحيوان وعالم الإنسان، وإقامة العلاقة بينهما؛ لإقناع الطفل بأنها من البشر للخروج من الذات والثان والأنا 
نفسها مع التغيير في الأسباب التي دعته إلى المجيء

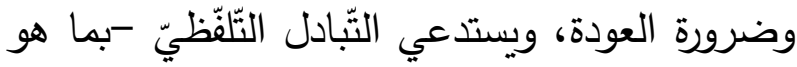
تأثير وتأثّر، فعل وانفعال، في البّياقين - وجود طرفين وبندي

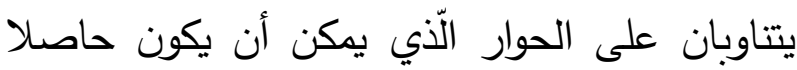
بالفعل أو حاصلاً بالافتراض.

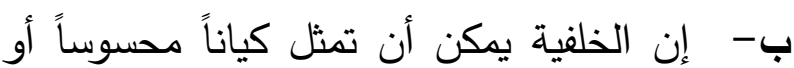
مجرداً في أشكاله الهندسية للخلفية يوضحها قولها:

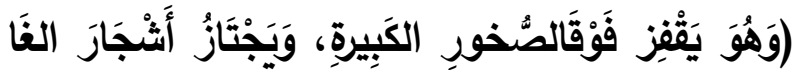

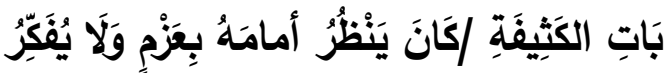

إلالِ بلِقَاءِ يوجاي) r-نظرية الجسدنة: تحاول أن تثبت أن الأذهان تتقيد بأنواع التنظيم المنعكس من العلوم، يرتبط بفهم اللغة المجازية واستيعابها بفرضية التجسيد ارتباطاً قوياً

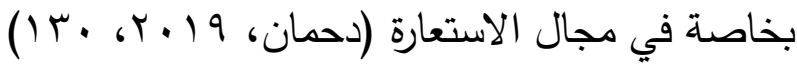
فمعنى أن تكون البنية التصويرية متجسدة هو أن تحدد طبيعة أجسادنا وتقيد نوع التصورات المشفرة وطبيعتها المتحققة عبر اللغة بالنظر في الكيفية التي يوفرها النسق اللغوي المراد استناداً إلى تصورات مشتقة من بن التجسد (Evans and Green , 172) ومثال ذلك: (كَلمَتَات جَارِحَة) فيما يدل على الألم بالاستعارة التي

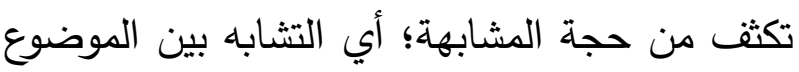
(ما نريد قوله وإثباته) وبين الحامل (ما نقوله لأجل تعبير أو إثبات أفضل)؛ إذ تدل على طبيعة الكلمات الغريبة وغير المجربة وتقيسها بطبيعة الجروح المألوفة، لينتقل المتلقي من الملفوظ الاستعاري إلى لى

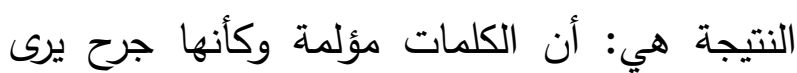

مُرَوجُ خَضْرَاءُ ..فكَّر أورفيو أندهُ قَدْ يَعِيش سَعِيدًا بِجَا

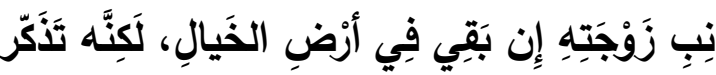

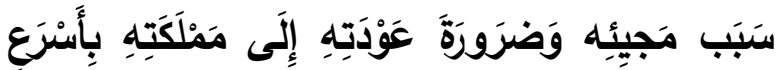

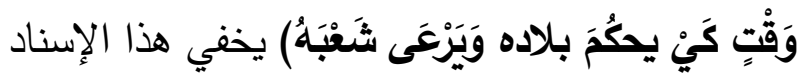
مساراً حركياً يعبر عنه الظرف (بجانب) رابطاً بين طرفين ومندرجاً ضمن بنية دلالية خفية تتمثل هذه البنية في أن كل الظروف المتعلقة بجانب لابد لهذا

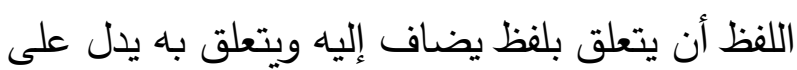
الاستقرار أي: مستقر في جانبه. نعتبر أن الملفوظ الأول = ما أجمل هذا المكان والثهان الثاني

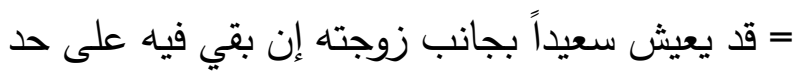
قولها، فإن هذا القول يعتبر خطابا حجاجيا، حيث يقوم الملفوظ "ما أجمل هذا المكان" مقام الحجة، ويقوم

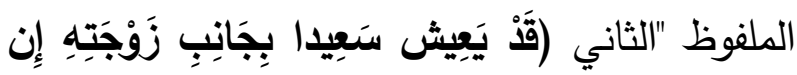

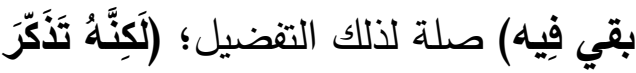

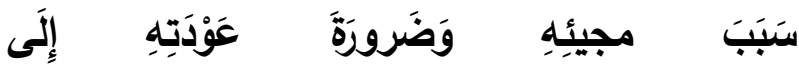

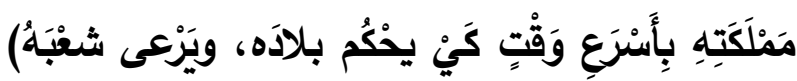

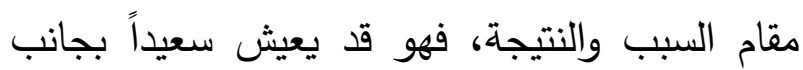
زوجته إن بقي في أرض الخيال "ليست هي الواقعة

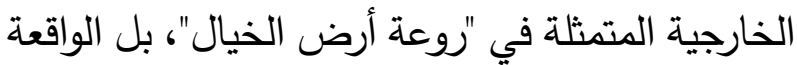
الخطابية المتمثلة في استقراره بجانبها في هذا المكان". فالقول يمثل مشهدين يتأسس الأول على تركيب

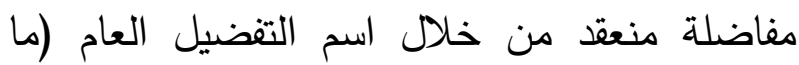
أجمل) وحامل لشبكة من العلاقات المرتبطة ببعضها والتي فضل بمقتضاها الاستقرار في المكان، أما المشهد الثاني، فيحافظ على عناصر المشهد الأول 
ومستوى السائل يدل على تغيير حدة السائل وكميته، ثم إن انفجار السائل في الوعاء يدل على فئل فقدان السيطرة على النفس. ويمكن إسناد خطره على الغاضب بخطر النار على ما يحيط بها ومما أكد ذلك صور النار المصاحبة في (تَحَوَّلَ الحبْلُ إِلَى تِنِّين

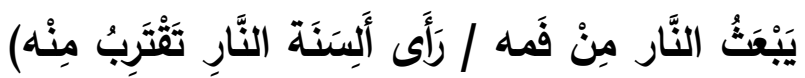
فكان هذا التطور وليد تفاعل علوم اللسانيات التداولية وسائر حقول المعرفة الإنسانية كعلم التربية البنائي وعلم النفس الإدراكي، والذي يهتم بما ينتجه الدماغ الاغ لئه

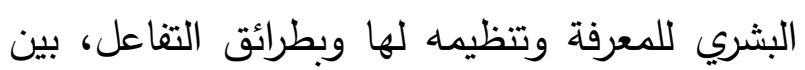

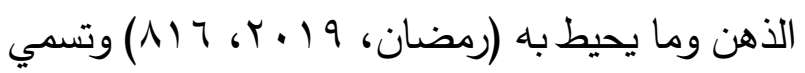
ماندلر (Mandler) مثل هذه العملية التي تقوم على (تلى

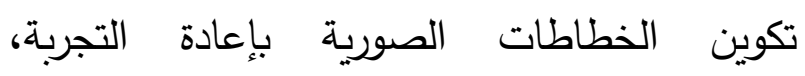
الخطاطات الصورية ويتم فيها إسقاط بنية في الفضاء الذهني في بنية تصويرية وتعتبر تجارب القاعدية المتكررة مع العالم تشكل الأساس الراسخ للهندسة لهندير

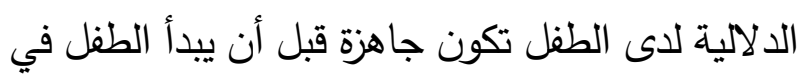
إنتاج اللغة والذي يعني كون التجربة ذات دلالة لدينا

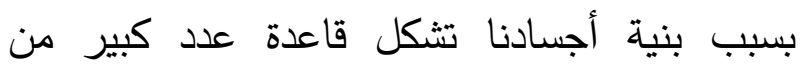
تصوراتتا الأساسية (Mandler, 2004) وتعتبر من فن فئن أسس القدرة على بناء التصورات ومفاد ذلك أن المعاني متأصلة في خطاطة القوة وغيرها من أنواع الخطاطات بما هي نتاج تفاعل قائم على التخوم بين مجالي التجربة الحسية الحركية والمستوى المفهومي والدلالي لتي بالاستتباع.
ويلمس، لتتم العملية التصويرية وتظهر القسوة مجسدة

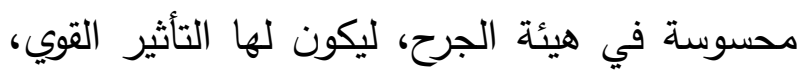

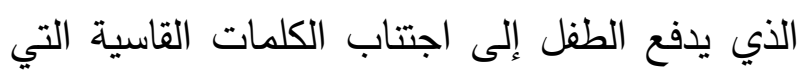

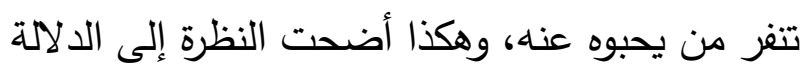
والذهن واللغة على أنها مجسدنة ونظر إلى التركيب

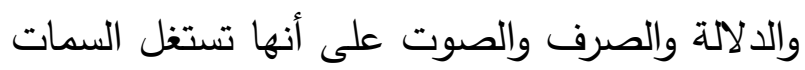
الكونية للإدراكات الحسية الإنسانية والبنية الجسدية

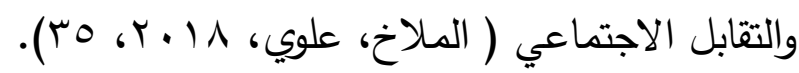
r- نظرية الخطاطة: يعرف جونسون الخطاطة

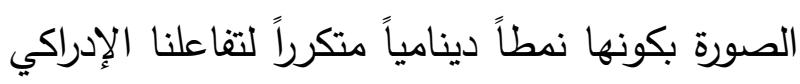
وبرامجنا الحركية، تضفي على تجاربنا انسجاماً وبنية (Johnson, M, 1987) حيث يستلزم المعنى في تجني دالة الاحتواء اشتماله عدداً من النتائج مثل تخصيص محله وتحديد حركته في مثل فنجان الثاي فكونه يحتوي على الثاي يقيه من التدفق، وإذا تحرك الفنجان

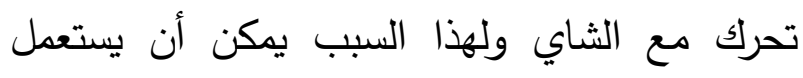

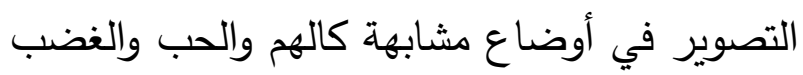
والحزن، فلأن الأوعية تفيد النشاط يصبح تصور

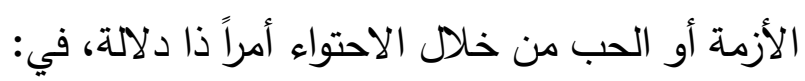

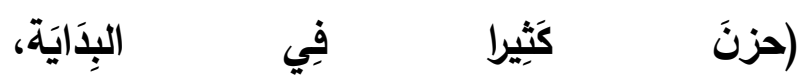

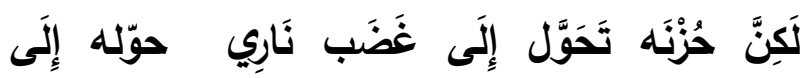
رَجُلِ جمَز) في التأكيد على التحول في رحلة الغضب إلبَ من المثير إلى الاستجابة في مسارات ضغوط الحياة عندما يتحول: محرك ثم معنى ثم فكرة ثم شعور ثم اتجاه ثم أسلوب ثم عادة ليعبر الغضب عن السائل الساخن في وعاء معين، ومدى التغير في درجة الحرارة 
/ تسير في الطريق/ قد تتعرض للصعوبات/ إلى أن تصل إلى مفترق الطرق وتنتهي إلى نهاية

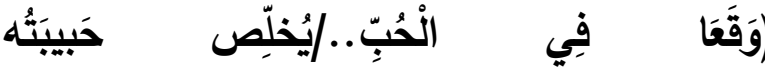

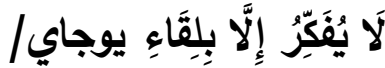

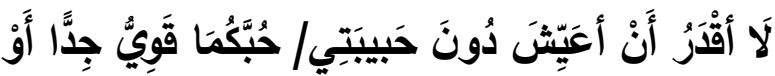

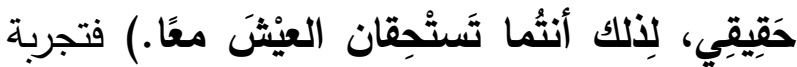
الحب تبدأ، وتسير في طريق، وتتعرض للصعوبات وفهم مجال الهدف (للحب) يتطلب استحضار التصورات الخاصة بمجال الصصدر الرحلة من البداية إلى النهاية وما يتخلل ذلك من محطات، وإسقاطها

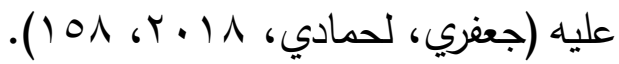
- وفي مثال آخر نجد الحب عمل فني: يتجلى المجال الصصدر فيه كون العمل الفني مشتركاً في تبادل التعاون، والمشاركة في الأعمال الفنية وإتقانها،

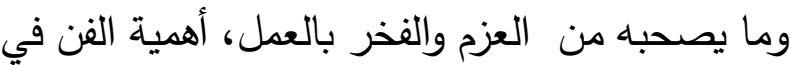
التعبير الوجهة النهائية والمجال التصويري الهدف: المتحابان يتبادلان المشاعر ، المشاركة والإخلاص في العابه

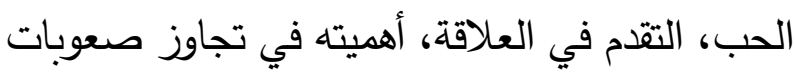

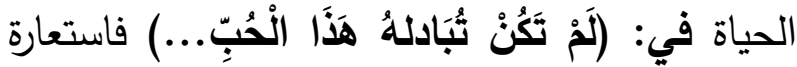
الحب عمل فني مشترك تتثقي طبقة بعينها من تجارب الحب، وتحدد مشابهة، بتصوير الدقابلة بين الحب فئب والعمل الفني المشترك وعن طريق استدعاء تجارب عن الحب ليس كلها، بل طبقة منها والتي تتثابه مع التجارب عن العمل لفني المشترك، القائم على تبادل التعاون بين أصحاب العمل الفني، وكذلك الحب يقوم على تبادل المشاعر اعتقاداً بأن العب قد بلغ مبلغة
צ- نظرية الذهن: عندما نتحدث عن الصورة في "الاستراتيجية الدعرفية"، بالمستوى الاستعاري الذي يمنح مظهرًا لتلك الأفكار عن المنهج وعادة عن بالكن التفكير وبالعكس، يمكنتا البحث عن استثمار ما كا

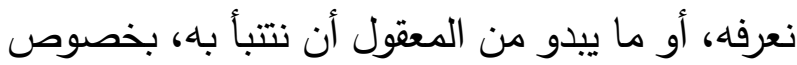

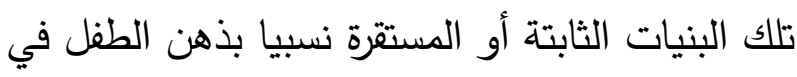
مرحلة معينة من النمو، بهذف تعزيز اختيار الأطفال للمسارات الذهنية التي تفضي إلى التعلم بما يشبه رسم

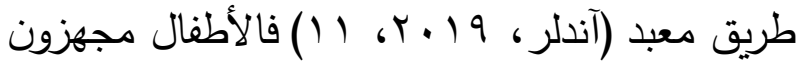
بتصورات قبلية ذات مقاومة صلبة، متثكلة من أنساق منظمة من المفاهيم والمعتقدات تحدد استعمالها، وعلى دئى المعلم أن يبحث في سبل تعبئة (تحريك) هذه التصورات القبلية بقصد تطويرها، بدل تجاهلها، والمعارف يجب أن تكون منظمة حول نواة من الدفاهيم

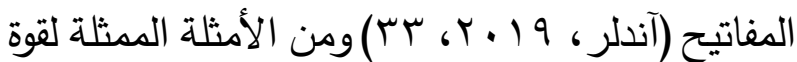
تدخل العلوم المعرفية ذي الأثر البنائي في مجال التربية، لقد شاعت نتائجه إلى درجة ارتفاع مخزون التاني الدفاهيم والاستعارات ذات الأصل العلمي، أو الطبي التي

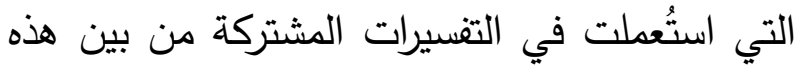
المصطلحات المتعملة سواء بخلفية إعلامية أو هلئ بدونها المصطلحات التالية: - الحب رحلة: وفي هذا المثال توضيح للمفهوم ففي الكي هذه الاستعارة نتعامل مع الحب باعتباره رحلة له: طريق / وبداية ونهاية/ وأماكن/ ومحطات؛ أي أننا نستعمل ترسيمة المجال التصويري الصصدر: الرحلة لمعرفة المجال التصويري الهدف: فتجربة الحب: تبدأ 
الإيحاء عن مشاعر الحب والكره. ونشير هاهنا إلى سئ

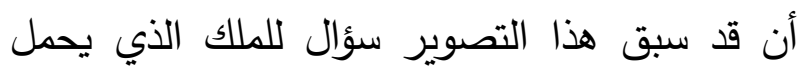
القيثارة عن زوجته: (كيف تختفي هكذا؟) ويميز جلبرت رايل (Gilbert Ryle) في كتابه مفهوم العقل

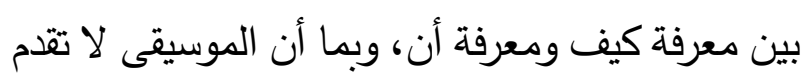

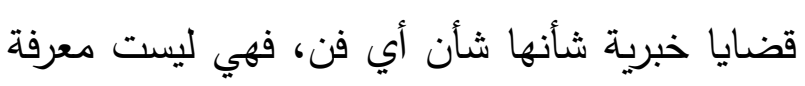

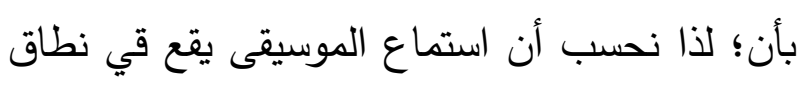

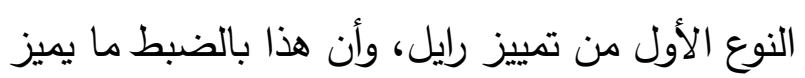

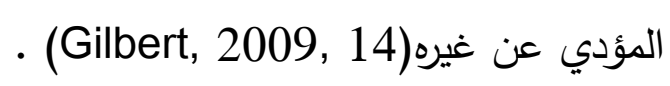
ثانياً: العلاقة بين الموروث التاريخي القصصي

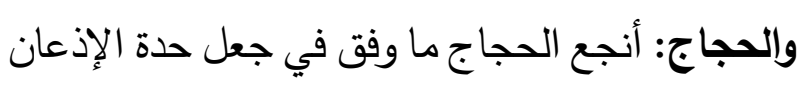
تقوى درجتها لاى المتلقي بشكل يبعثه على العمل

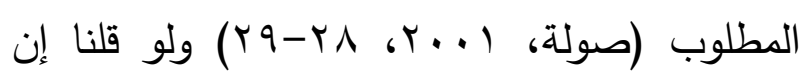
قصص الموروث الثعبي يفترض فيها أن الطفل ول الثل

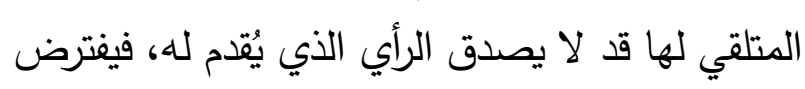

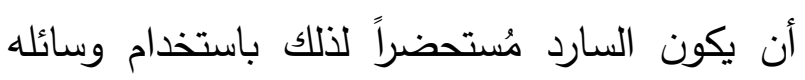

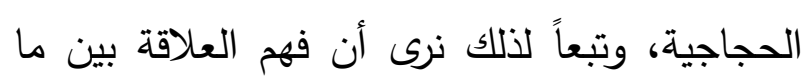

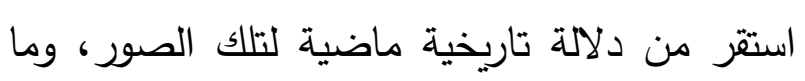

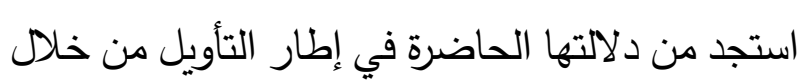

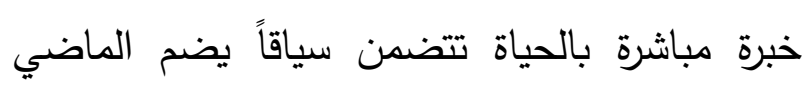

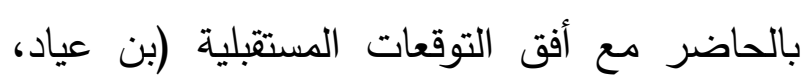

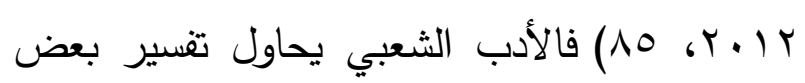
الظواهر الطبيعية كالفيضانات، وذلك ما يمتثل في تعبيرات الساردة عن (الطفو): (آثار طوفان محا مَعالمِم).
وجاوز الصعوبات في التعبير عنه (لايكوف،

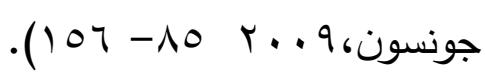
- الموسيقى لغة: يتجلى المجال المصدر في:

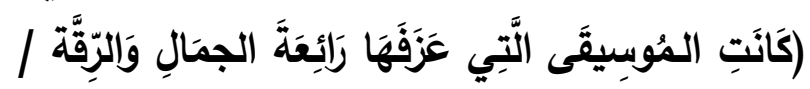

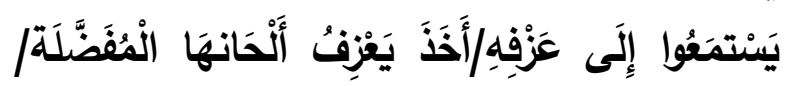

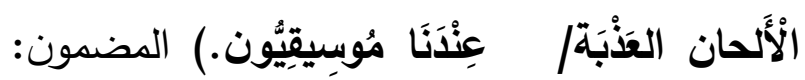

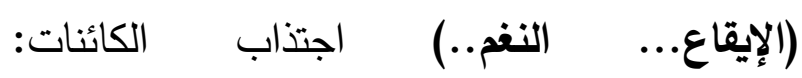

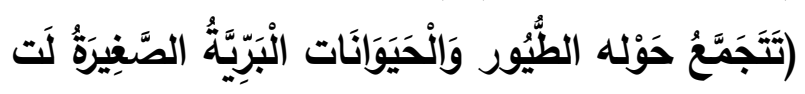

سنتَمِع

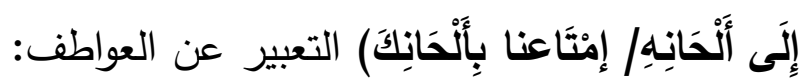
فيما يميز المؤدي عن غيره: (قََالَت المَلِكَة "عِنْدَنَا

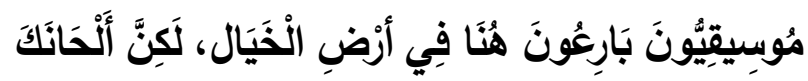

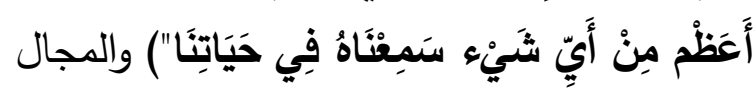
التصويري

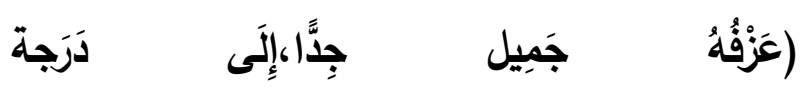

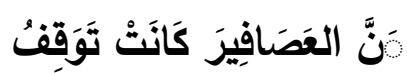

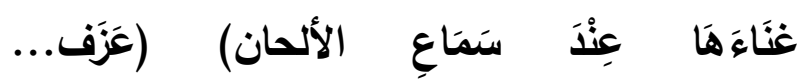

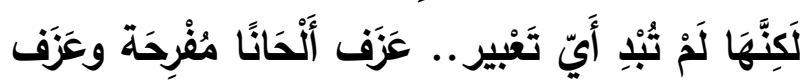

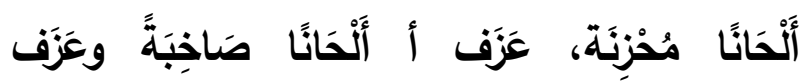

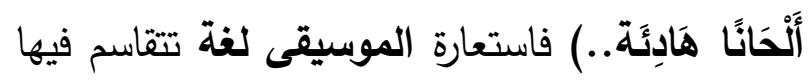
الموسيقي مع اللغة العديد من الصور المشتركة

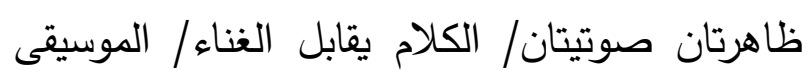
شكل من أشكال الأصوات والإيماءات التواصلية/ التعبير عن العواطف/ الإيحاء عن البكاء والصخب/ لإلـاءل 
بالمعارف التي تسهم في تطوير ملكة البحث العلمي من خلال التفكير بالعدول والانزياح(مصلوحي،

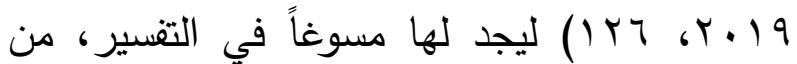
خلا الصور الذهنية والمرئية، فيربط بين أحداثها ويبتكر لها مسبباتها، بقدراته الفكرية والعقلية التي يعرفها وطريقته التي يمتلكها؛ فالطوفان: من الموجودات الحسية، وما يتجلى في القصة من مجموعة الصور الذهنية ارتسمت من الواقع الخارجي حيث يستعير الخطاب الصندوق للاستعمار الدقاوم في البرازيل عند تصوير العدو وكأنه طوفان جارف ليطن باعتباره سيولا جارفة، والمياه الجارفة أحداث طبيعية غير محكومة بإرادة واعية، يخفي هذا المنظور والاختيار التجسيدي الاستعاري الاختيارات الإرادية والمسببات الواعية للاستقلال لمن هم محبوسين في النيان

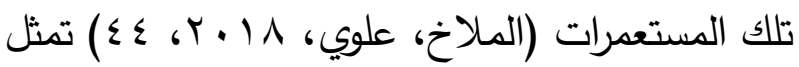
فيها: الفتاة المحبوسة داخل الصندوق: التطلع إلى الحرية/ والجدة: الأصالة/ والتمساح الحارس: قيود دلهن

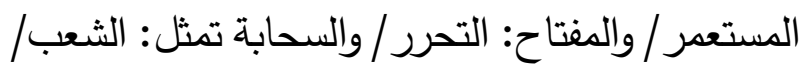
تحول عظام التمساح إلى سحابة: على الاختفاء التدريجي/السحابة اللامعة: وعي الشعب لفقدهم لحريتهم وهويتهم وشبابهم بسبب ذلك المستعمر ؛ ولهذا فإن هذه الاستعارة ليست مجرد استعارة مبتكرة ولكنها تمثل تحدياً للتصوير التقليدي لخبرة بعينها (سيمينو،

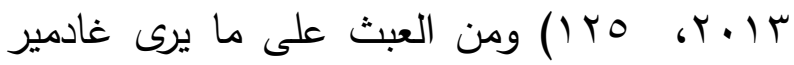
أن نستعيد الماضي ليعيشه طفل فئل المستقبل من جديد في حد ذاته من غير أن تُسلط لمانط
نلحظ أن هذا التصور نتيجة مباشرة، فالمعرفة لصورة الطوفان تكثف عن معانٍ متصورة أخرى يعيشها الإنسان وينفعل بها في تلك الصورة الذهنية الواقعية

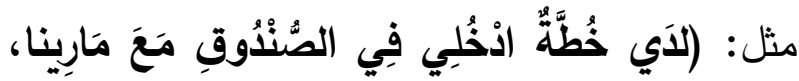

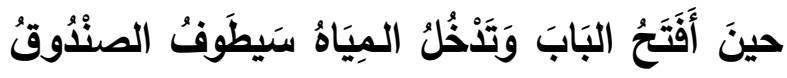

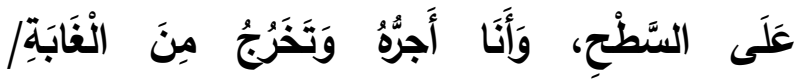

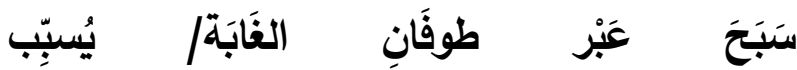
أَمَطَارًاً عَزَيرةً الْغَابَة قََْْ طَافَتَ/وَجَََ يَطوف الصُّنْدُوق ابنه عَلَى سَطْحِ الْمَاء/أَمَيرَة تَرَى الجمَال يَطْفُو عَلَيْهَا) فالغابة، والصندوق، وجمال الفتاة، كل هذه المعاني مما احتوته القصة من الصور الذهنية، والمعاني المحسوسة؛ لتتداخل عناصر الطبيعة مع الإنسان في نسق فكري واحد، وليس هذا التلاقي وليد مصادفة بقدر ما هو طريقة وعي للمحيط يتداخل فيها الخارج

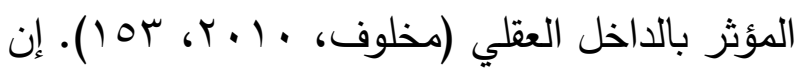
العلاقة بين الداخل والخارج هي علاقة الخارج الذي يسعى عقل الطفل إلى تفسيره، وتحليله من أجل معرفته، في المعاني التي يصورها الذهن؛ بتضمنها خُطة طفو الخشب على الماء، التي ورد فيها اللفظ بصيخ متتوعة تتضمن صيغ مختلفة تتمثل في: (سيطوف/ طَوف / طَافَتْ / طوفَان/ يَطوفُ ) وهاهنا نجد المشابهة في الطفو بين عدة أشياء مختلفة؛ تسهر في ترسيخ تلك الخطة التعليمية التي تدعو إلى التنكير في البحث عن حل المشكلة، وتعمل على تزويد الطفل 
والموضوع مجال يقدم لنا العلم والخبرة بالعالم معاً في

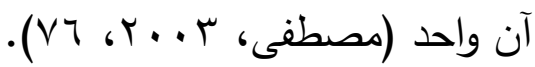
قوام الحجاج فيه: أولاً: استحضار الإثبات المعرفي، وتمثله لاقتفاء أثره، والثاني باعتبار الاستدلال مكرساً

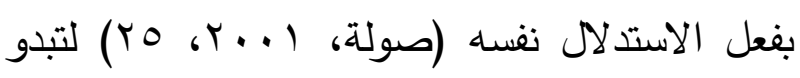
أهمية المنقول في نقله للمعرفة من مرحلة إلى أخرى للتوصل إلى الحقائق المعرفية المشتركة، مع التتبه للإسقاطات بالتوقعات الذاتية، ومثل هذا التقدير للفعل الفردي ضمن الكتلة الجماعية يحملنا على مراجعة الموقف غير العلمي من الأحكام السابقة، وعقد أواصر القربى بين الأزمنة التاريخية (بن عياد، ب ( • ب، 9). 1- استحضار الإثبات المعرفي في التصوير: ترتبط البنية الدلالية بالبنية التصويرية وذلك لوجود عنصر الرمز والتمثيل في الاستعارة والمجاز، وإذا عمقنا النظر في هذا الارتباط، فالبنية الدلالية هي التصويرية فكل ما يتصور يعبر عنه في اللغة وتعبر عته اللغة كما بُني؛ أي كما هو متصور في الذهن ومن هنا فالبنية الدلالية هي إسقاط للبنية التصويرية في مجال

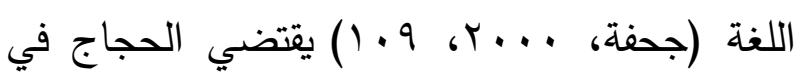
الصورة يقتضي (إقامة الدليل/ إيجاد العلة/ ادعاء

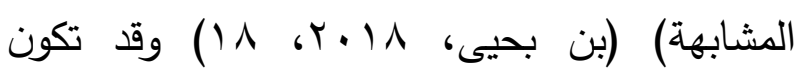
المشابهة بين عالمين متباعدين؛ عالم الإنسان والجماد في قصة أميرة في الصندوق: (غادر نيكسيواكا للبحث عن علاج لأبيه بِسزعة السهم):
عليه الثقافة الراهنة ووصل الحاضر بالماضي نجد أن الفهم المعرفي هو التعبير الأسمى عن علاقتنا بالماضي وهي الفكرة التي سيعبر عنها ريكور بطريقته الخاصة (بنكراد، Y I (Ricoeur) ففي قولها: (أتذكّر يَا بَابَا كَيْفَ كَانَ شِيرُو الْأَزْزْ كَعْكَة يُحبب مَا رأيكك أَنْ نقَطع الثَّجَرَة وَنَصْنَع مِنْهَا مِطْحَنَة، وَبِهَا

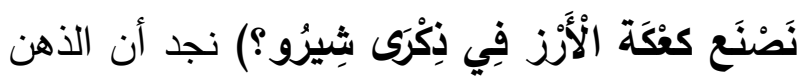
البشري غني يحمل تصورات عدة ويمثلها عبر العالم الفيزيائي الكائن البشري، وهي قدرات معرفية ناتجة

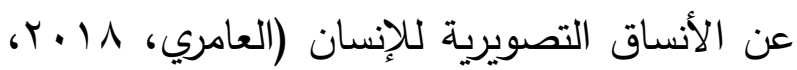
0 1 ) وفي هذه الحالة، فإنه يشكل معنى قابلاً للإدراك في مستواه الأصلي.. (الاستعمالات الاستعارية لكلمة شجرة) حيث يمثل الاعتناء بشجرة الكرز وبثمارها المعرفة وما تقتضيه من الأفكار التي ينتجها الذهن بصورة مطردة قابلة للوصف بصورة آلية انطلاقاً من أن لكل فكرة بنية يفرضها عمل الذهن (لايكوف و جونسون، 1 ( • r، 909) والخطاب في تلك القصص رؤية شاملة لتلك الثقافات ترمي الساردة من خلاله إلى التأثير في الطفل؛ لذا نجد في تجسيد الصور في هذا الوصل التاريخي عملاً حجاجياً متراوحاً بين مبدأين نقيضين هما التوجيه الإثباتي بالميل إلى التمسك بالوقائع التاريخية السابقة، والتوجيه الإلزامي بالميل إلى الدعوة إلى الاستفادة من الصور المعرفية؛ ليصبح ذلك من مسؤولية الوعي الذاتي، فالاستبصار المثر يكمن في رؤية الخبرة كمجال سابق على الذات 
الحالة التي ورد فيها التشبيه، وبذلك يزداد المعنى وضوحاً فيقتنع به، فالتمثيل -إذن - وسيلة حجاجيّة ولهية ذات تأثيرات في المتلقي من جهات عدة، فهو خطاب للعقل بوصفه ينقل العقل من المعنى في الحالة التصوّريّة العاديّة إلى الحالة التصديقيّة؛ لأنّه بمثابة إحضار المعنى المدّعى ليُشاهد كما هو في الواقع، فكأنّه -والحال هذه- يقول لك هذا هوَ انظر إليه

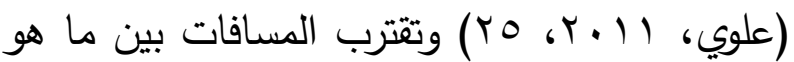
محسوس وما هو ملموس؛ إذ يجعل من قيمة التثبيه

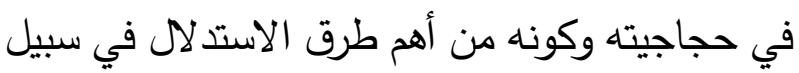

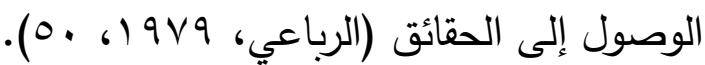
r - اعتبار الحجاج مكرساً بفعل الاستدلال نفسـه: مما يسهم في القدرة على رسم وجهة نظر محددة، وكذا في البنية المنطقية للخطاب الحجاجي التي تجعل الطفل يصل إلى مرحلة الإقناع بما يطرحه المرسل

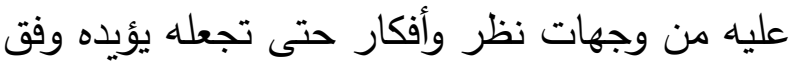
منهجية منطقية مما يتطلب حدوث عمليات ثلاث

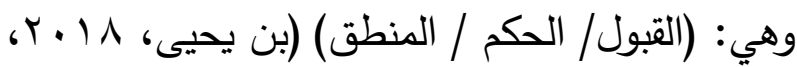
•r) وذلك بالمقاربة بين البنى المعرفية للصور وحوارية الدلالات المتباينة فيها) بحيث لا يمكن التّسليم

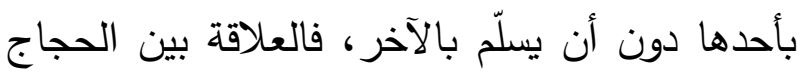

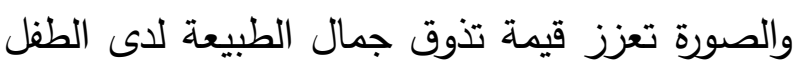

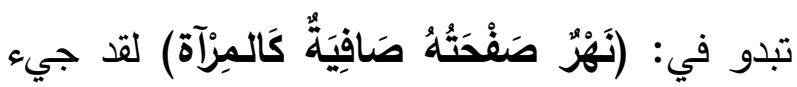

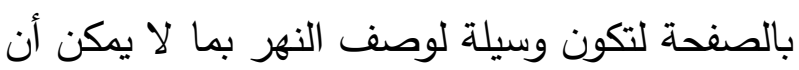

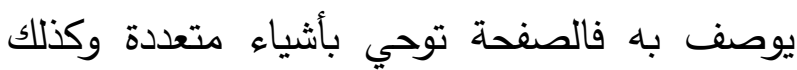
النهر وهما في إيحائهما لا يتشابهان فالنهر ينتمي إلى بلى بـاء
عالم الإنسان: الفتى + انطلاقه

$$
\text { اللبحث عن دواء لأبيه + سرعته للحصول على الإنسان }
$$

عالم الجماد (السهم)+ انطلاقه

للتمكن من الهدف + سرعته في إصابة الهدف. في التعبير عن حرصه على علاج أبيه حيث جاء

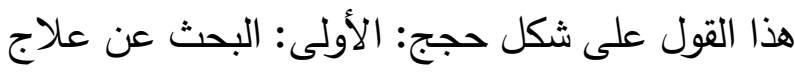
لأبيه. الثانية: السرعة القصوى في محاولة توفير العلاج؛ فسرعة الفتى في البحث عن علاج لأبيه تفوق التصور والإدراك،، وتصور الساردة انطلاقه في البحث عن الدواء لأبيه بالسهم المنطلق، وعملية التفاعل الإيجابي، تتطلب أربع مراحل متتالية هي: (الانتباها الفهم/ الإقناع/ الاستجابة) وكل مرحلة تستهدف تغيرا جزئيا تدريجي؛ فكل مرحلة توصلك إلى المرحلة التي بعدها حتى تبلغ غايتها والنتيجة: السرعة في البحث. تجمع بين الحجتين صفة؛ وهي السرعة وجعل البحث شغله الثاغل؛ لكي يصل إلى هدفه المنشود ويصل إلى العلاج المتوخى، قبل فوات الأوان، ومن التقريب بين عالم الإنسان والحيوان: عالم الإنسان: الفتى + لعانى حبس العملاق له في الصندوق + مساعدة الأرنبة له لهان الإنس وإنقاذه

عالم الحيوان: الأزنبة + حبس العملاق لها في الصندوق + مساعدة الفتى لها وإنقاذها فخرافة الأرنبة داخل الصندوق، لا تعلم فقط ولكنها

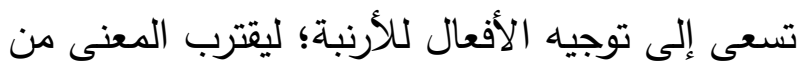
الطفل في الربط بالعوالم المختلفة ويقوم باستتتاج 
أ-علاقة مكونات التصوير الخطابي ومواضعها بالحجج: لا تتفصل الصور والرسوم عن تواجدها فهي ليست زخارف تضاف للأفكار والقيم وصيخ ترابطها، بل إنها تتدخل بها وتتلاحم معها مما يسهم في الحضور الحسي للقيم التي يحاجج بها من ذلك الرسوم في القصص والتي تربط الصورة بمكونات الخطاب، فقد تلتحم بالإيجاد فتحيل إلى النص أو إلى المتكلم، أو إلى المتلقي، فللمواقع التي تشغلها الصور أهمية

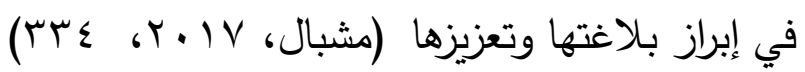
وقد سعت أدبيات علم النغس الخاصة بالإبداع إلى فهم العلاقة بين الخيال والصور ، لعلها تتمكن من تقديم العون أثناء تربية خيال الابتكار لدى المبدع وتحدثت لهتي عن (التصور الارتسامي) (الفيصل، 99191، 9 ب) وبالنظر إلى الرسوم من خلال رصد العلاقات الطبيعية بين الصفات في الشكل المميز لكل شعب وما تتميز به بلاده من الطبيعة والتي من خلالها تتجلى لنا الحركة المصاحبة للتعابير اللفظية والأيقونية، بداية من الاهتمام بتصميم الغلاف وتوزيع الرسوم والكتابة عليه؛ حيث كان في الجانب الأيمن العلوي العنوان بخط كبير وأسفل منه بخط أصغر يحدد بلاد الحكاية، ومن ثم أسفل منه اسم الساردة ومصممة الرسوم، لتشتمل صورة الغلاف في القصة الأولى: على صورة رجل بالزي الياباني والرماد الذي يتناثر من يديه على أشجار الكرز، وفي الثانية الملك بزي أوربي، وعلى رأسه التاج وتحت إبطه قيثارته، وفي الثالثة يد لا يظهر صاحبها وطرف من الزي الصيني
مقولة يحال إليها بوصف الصفاء وأن متصور المرآة يمثل النموذج الأولي للإحالة إلى الصفة فعبارة (نهر صفحته) لا تحيل إلى شيء بعينه، إنما تحيل إلى نوع من الأشياء و تشتمل على جملة من الخصائص تكون وصفاً للمستوى الأعلى في الصفاء التي تربط المرآة بالصفحة، والعناصر المشتركة هي نتاج للمقولة.

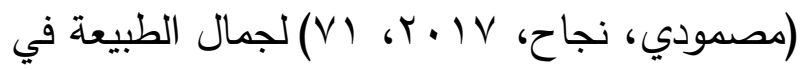
ذلك المكان، عندما شبهت، صفاء صفحة النهر بالمرآة التي تعكس ما حولها لثدة صفائها، وقد جاء هذا القول على شكل حجج: الأولى: صفاء صفحة النهر| الثانية: المرآة العاكسة، والحجة في ذلك فكرة مفادها شدة الصفاء في ذلك النهر، ومن هنا جاء وصفها بكونها حججا إتّصاليّة أو قائمة على الوصل. إنّ طرائق الوصْل في الحجاج، فحين نصف خطابا ما بأنه خطاب حجاجي، فيعني ذلك احتواؤه على ملفوظين اثثين على الأقل: حيث يقوم أحدهما بتعزيز الآخر وإسناده، فيسمى الأول حجة والثاني نتيجة ويمكننا أن (Anscombre et Ducrot, 163) نرصد في القصص مجموعة من الصور الحجاجية تتصهر الصور فيها في مكونات الخطاب وترمي إلى تحقيق أكثر من غاية؛ فتحليل الصور ليس سوى تحليل للحجج، وتحليل للترتيب. (الاستهالال والاختتام) وأن انصهار العبارات عندما تدرجت فيها الجمل بين المتكلم والمخاطب يتجلى ويظهر في: 
القصص يهيمن عليها اللونين (الأحمر والأخضر) بارتباطهما بكافة قصص المجموعة لينقل اللون أفكار وعادات ومعتقدات قد تختص بالمؤلفة وما تتمتع به من حركة وحيوية ونشاط ثقافي والذي أشارت إليه في نهاية القصة الأخيرة

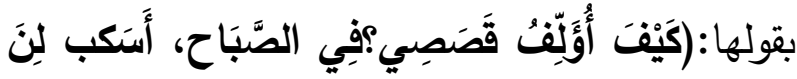

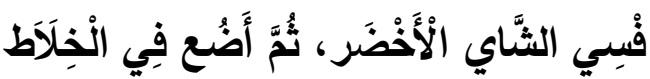

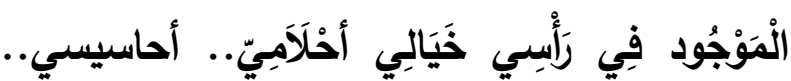

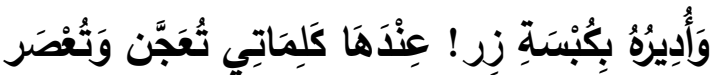

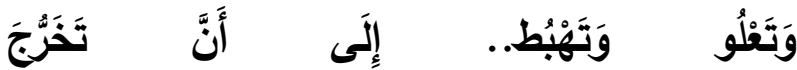

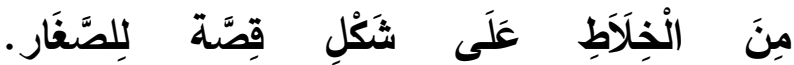
نَجَحَ الْخَلَطَطَ حَتَّى الْآنَ فِي تَأْلِيف 130كتابا...) لذا نجد اللون الأحمر مهيمناً في لاليط تعبيراتها:

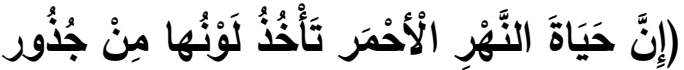

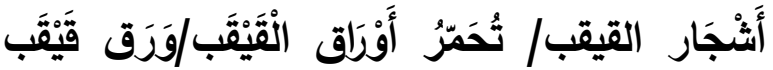

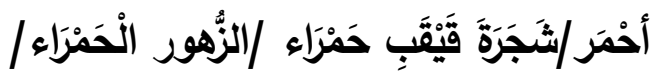

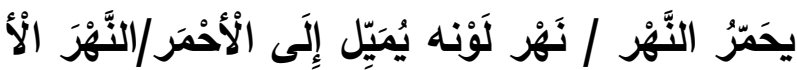

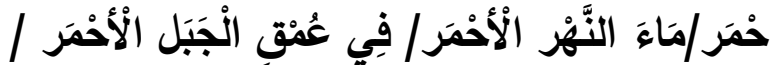

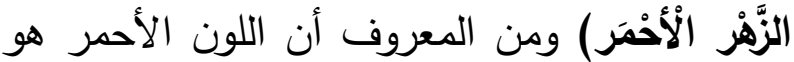
أحد ألوان الطبيعة في التعبير عن الدفه والعاطفة والثجاعة والإثارة، ويعد محفزا للشهية فقد استخدم في العديد من شعارات المطاعم الصينية. ج- الصور في الموروث الثقافي اختباراً للذات: فالنظريات ذات الإطار والأساس المعرفي، توفر الدعامة المعرفية للأوصاف المنجزة في أدب الثعوب
بنقوشه، وعلى كف اليد ورقة قيقب حمراء كبيرة، وظل أبيض لساق الأثجار وأوراقها، وفي القصة الرابعة: فتاة سمراء البشرة بشعرها الأسود الداكن مرتدية الزي الإنيا البرازيلي حاملة مفتاح الصندوق بإحدى يديها، ومن خلفها الغابات الخضراء تتخللها أوراق باللون الأخضر ، فالقصص طريق لنشر الفضيلة كما في العلاقة البسيطة والصلات الإنسانية؛ فالأشخاص الطيبون بعطائهم يثمر كل ما حولهم، لتحمل قصة أشجار الكرز رسالتها التربوية التي تتركز في التحذير

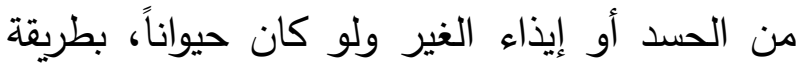
تقربه من الواقع في طرحه؛ ليجسد لنا المكان في ثماره الملامح النفية والاجتماعية بدقة، ويثبت اللون الأخضر حضوره عند حديثها (الأوراق الخضراء) المروج خضراء) وكذلك في رسم الغابات هيمنته في دلالته على النماء والخصب في تلك في الغابات والأشجار ؛ فاللون قبل اندراجه في البنية القصصية وتشكله نصياً معزولاً عن واقع السياق مجرداً من أية الثالية قيمة اجتماعية، بينما تبقى له بنيته الداخلية التي تحددت في ضوء قوانين الطبيعة. ب-صور الأسلوب والإطار النوعي: فالصور تكتسي أشكالاً ووظائف مختلفة وفق أنواع الخطاب وأنماطه التي تتدرج فيها، وهاهنا لا يمكننا النظر إلى صور التشبيه والاستعارة والمجاز والرسوم باعتبار ما تقوم به من وظائف جمالية، بل لما تقوم به من وظائف إقناعية مع مراعاة شبكة العلاقات النصية التي تربط بينها، وبناء على ذلك فمن الملاحظ أن الصور داخل 
الذي تكتفي بإدراك الثيء في اللحظة في انفصال عن

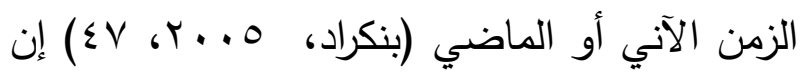
وضع الأفكار السالفة على محك الاختبار ينفي تماماً إمكان أن ينطلق القائم بالتأويل في تأويله من أفكار

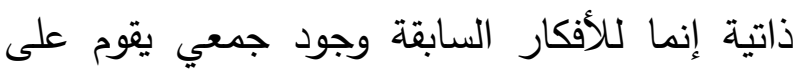
المعرفة وتبقى تلك الأفكار متجددة دوماً بالعلم والمعرفة مادامت تتدرج ضمن التاريخ الإنساني في لتئي الذاكرة الجمعية، قد لا تعوذها المصداقية ولكنها تبقى لإنى

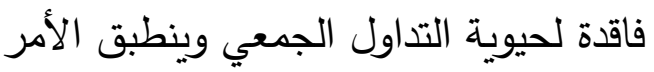

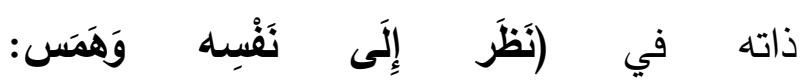

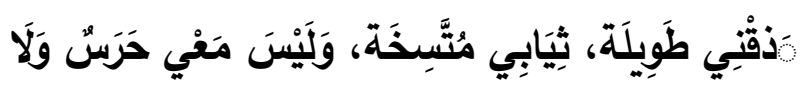

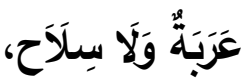

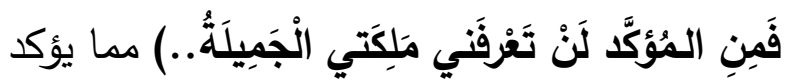
أن المعرفة مرتبطة بالعلامات التي تُشير إليها، وفي

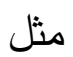
(رَحَلَ المتلكِك وَحَدَهُ مِنْ دُونِ حَرسِِ وَلَا عَرَبَاتٍ تَنَقُلُه..

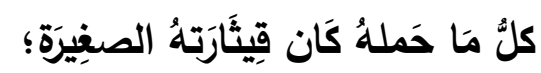

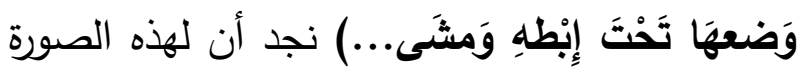

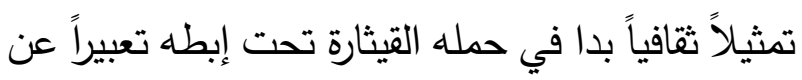
الحب والسلام، كما بدا في قطع المسافات... وفي هذا التمثيل التحقيق الثقافي لأهميتها عند تلك الثعوب؛ لأنها آلة تضرب بجذورها في أعماق التاريخ الإغريقي

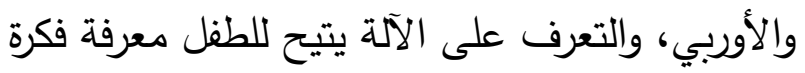
التواصل التاريخي وارتباطها بالارتباط الأسري والحياة

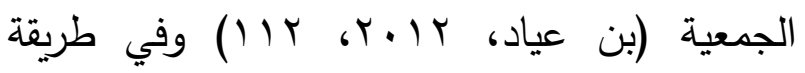
الإمساك بالقيثارة تحقيق صوري للنموذج الأعلى
في مستويي التحليل الأساسيين: المستوى المصغر المنجز على البنيات اللسانية والأسلوبية...ومستوى التحليل المكبر للبنيات الاجتماعية التي يمثلها

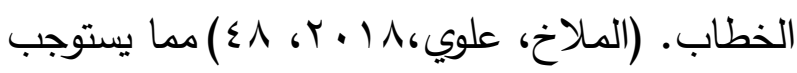
الإسقاط النفسي على النص متمثلاً في استجلاء

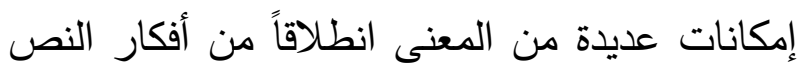

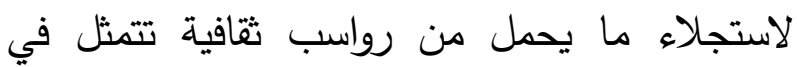
(الاحمرار) فهو وجود إمكاني نوعي ذو كيان مجرد

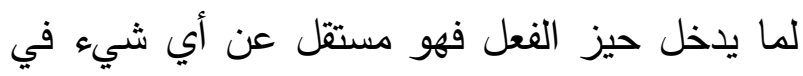
قولها: (عما حصل معها عند حديقة الزهور الحمراء) تتقل الطفل آنذاك من الحيز المجرد إلى حيز مجسد دخلت فيه عدة مركبات: أحدها تجريبي: حصول الأمر في حديقة الزهور الحمراء. ثانيها زمني: إذ تم حصول ذلك الأمر في سياق زمن مضى. ثالثها مكاني: لأن حصولها عليه لا يمكن أن يكون

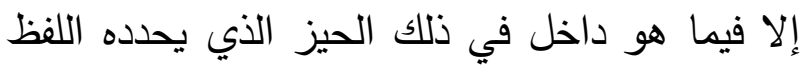
. (عند) رابعها حالي: إذ وصفت الزهور باحمرارها، وإذا كان الكيان الأول مجرداً، فإن الكيان الثاني علائقي، ترتبط

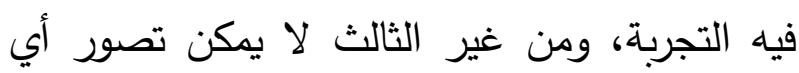
شيء، وغيابه معناه أننا سنكون أمام حالة هشة وزائلة و عرضية لا يمكن أن تتتج معرفة أو إدراكاً، فالإحالة

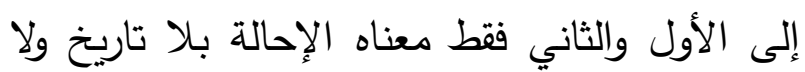
مستقبل ولا ذاكرة إنه لحظي مثله في ذلك مثل الحيوان 
المتمثل في (الاحتضان الأمومي) وقد ركز علم النفس أسطورية قابلة لأن تصبح نماذج عليا تقيدنا في فهم

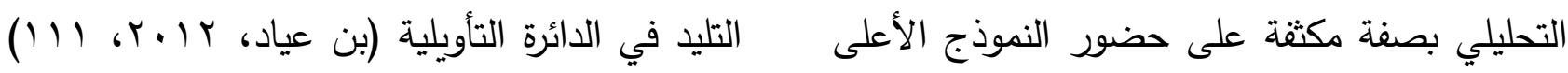

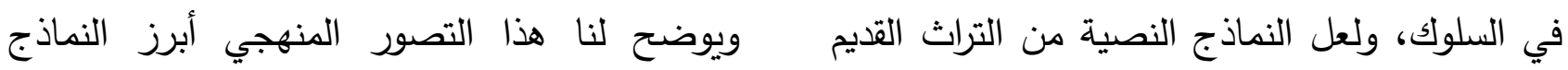

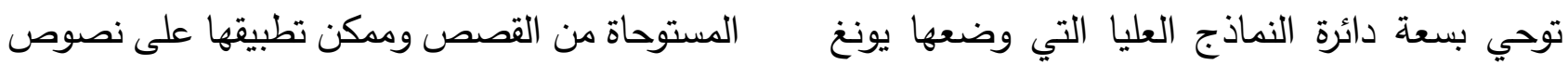
(Yong) طبقاً لما يتردد في هذه القصص من رموز أخرى:

\begin{tabular}{|c|c|c|c|}
\hline الطقس الثقافي & في المجموعة القصصية & 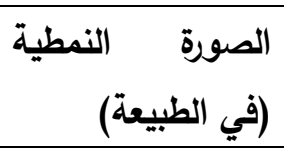 & الأعلى النمو \\
\hline مؤسسة & الغابة المطيرة & مطر + & النقالنزوع إلى \\
\hline مؤسسة الجمعية العائلة/ الحياة & سكان أرض الخيال & أرض ل + مكوناتها الطبيعية & $\begin{aligned} \text { الأمومي الاحتضان } \\
\text { الأمي }\end{aligned}$ \\
\hline النظام السياسي & الشمس تشع على البلاد & الشمس دائر حول & الإح- الموقع \\
\hline في السفر على متن قارب رغبة & ركبت قارباً عبرت به النهر & اجتماع + الماء & ع- الجي \\
\hline 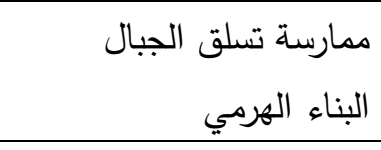 & يققز فوق الصخور الكبيرة ويجتاز ..... & الجبل مشرفاً على & 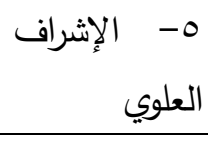 \\
\hline ركود المغامرة & ولجكر باستخدام الحبل، فجعله حلقة ربطها & المجهول الفضائي & الع-طلب \\
\hline التغرات & الكهف آثار طوفان محا معالم مدخل & الظوفان ......في & V - V -المركزية \\
\hline إنشاء الأساطير & 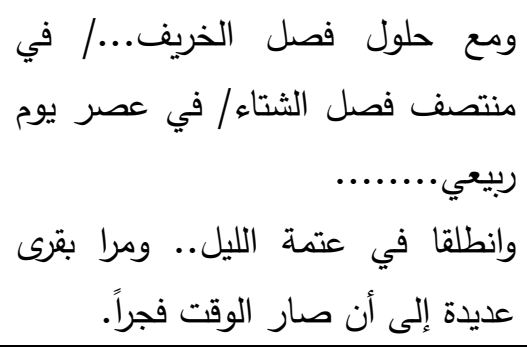 & تداول الفصول & 1-الدورية \\
\hline
\end{tabular}


ه-قّّم التصوير تفسيراً أكثر ملاعمة لإنتاج الاستعارة

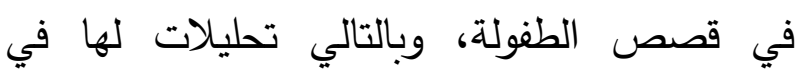
النصوص المختلفة من خلال أدوات وآليات تجسدها كفاءة المتكلم التعبيرية. 1-تلعب الاستعارة دوراً مهما في النص الموجه للطفل، لتأكيد الفكرة المراد إقناعه بها أنها قد تدفع

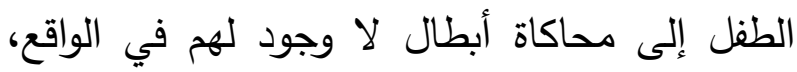
وترسيخ المعرفة من خلال تصويرها للمعرفة بطرائق قددا تتمي قدرة الطفل على التفكير والتأمل. Vيُسهم في تحديد المعنى، ودفع اللبس وتطوير القدرات الإدراكية والذهنية وتعويده على تحليل الخطاب. 1- تسهم النظريات المعرفية في التعرف على طرائق استخدام أدواتتا الثقافية التي تصبح أدوات معرفية لتكوين نماذج وأشكال للمعرفة حول فكرة ما، تستخدم في تحليل وبناء المحتوى المعرفي وليس كمخزن

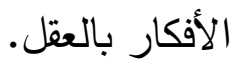

9- استطاعت الساردة أن تتجاوز الصورة المرجعية إلى صور أخرى ذات دلالات وأبعاد تتنمي في ج جوهرها إلى عالم الخيال من خلال التصويرية

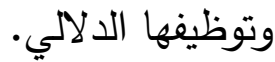
• 1- الوصف لجمال الطبيعة في أرض الخيال وربطه

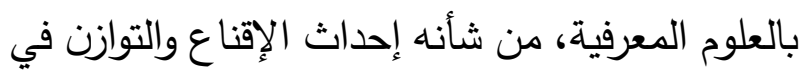
نفسية الطفل المتلقي.
فالتصوير بهذا لا يكون فقط نزعة علمية بل يتجاوز

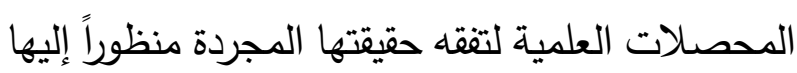

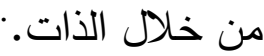

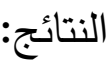
ا-ترتبط الصور في مجموعة دنيا الحكايا، بالحياة عند الشعوب، ومن خلال ترابط الحقول المعرفية المتتوعة عن تلك الثقافات استخدم مزيج من الصور التقليدية والمبتكرة واستحداث تصور مجدد لتلك فلك الثقافات المستهدفة، ليكون لذلك تأثيره على الطفل.

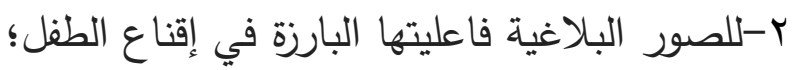
خاصة عندما يفتح الباب للتفسيرات والتأويلات المحتملة المختلفة لإيجاد وجه الثبه؛ لأنها تنقل المتلقي من المعنوي إلى المحسوس، وفي هذا تدرج

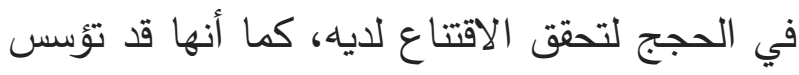

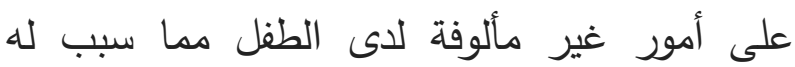

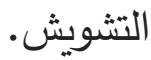
ب-من المآخذ على بعض الصور احتواؤها على بعض القيم الدخيلة على المجتمع، مما قد يُسهم في ترسيخها ونشرها وتقديمها على العديد من قيمنا.

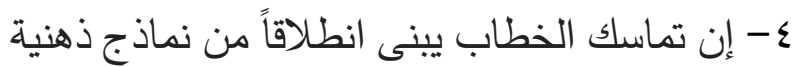
محددة ثقافياً وذاتياً، يثبت أن النسق التصويري شأنه

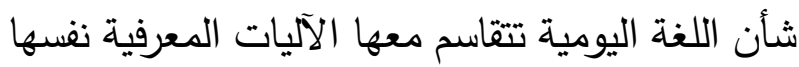
التي توجه السلوك بعامة وسلوك الطفل بخاصة. 
والمثبت والمبني في الذهن والقائم على ترابطات مترسخة بين المجالات التصويرية. 1 ا-تعد بعض الاستعارات مخاطرة من الساردة فبعض الأطفال قد لا يعي هذه الاستعارة في مثل الصندوق والأميرة، وقد يرى بعض الأطفال أن هذه الصورة هي أقرب الصور التي تمر بها البلاد المستعمرة. التوصيات: - (الت

1-إن كانت العلوم المعرفية مجرد تقليعة عابرة ومؤقتة، قدمت في وقت من الأوقات كل الإجابات، وإن كانت لم تتتج سوى بعض الصور والاستعارات الفضفاضة التي طواها النسيان، إذا كان هذا حالها إلا أنها ومع التطور المعرفي باتت تستحق منا أن نفحص بجدية مسألة مردوديتها. ץ-اختلاف الاستعارات العلمية عن الأدبية في احتياجها إلى الشرح من هنا كانت الحاجة إلى تقديم جدول شجري في نهاية القصة كمرشد يسهم في إرشاد الطفل وإعانته وتتبيهه للتصوير الوارد في

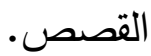
ب-الاستفادة من الموروث الشعبي في تحفيز خيال الأطفال باستخدام الأدوات المعرفية، وتوظيف الحواس المختلفة في ظل العالم التفاعلي التعاوني، بما يحقق النمو الإبداعي الخيالي لديهم.
1ا-1إن الفهم المناسب للاستعارة يتطلب لاهتمام بصورها ووظائفها في اللغة فضلاً عن الاهتمام بدورها

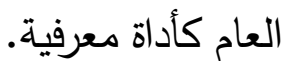
rا- تسهم المعرفية وصور الخيال في توضيح ومعالجه ثقافة الشعوب في الإطار المعرفي، باعتبارها تقنيات للإقناع. س ا - إن الانتقال باللفظ من حقله إلى حقل آخر حيث تنزع الكلمة من مجالاتها وتضاف إلى استعمال آخر فيترك اللفظ القريب المألوف إلى مجالات أخرى بعيدة مبتكرة ذات فاعلية يزداد تفاعل الطفل معها. ع ا- المزاوجة غير الملائمة بين الوسيلة والهدف مقدمة كسبب يشرح لماذا تشير الصورة إلى إبراز سلوك غير ملائم؛ لذا فمن الضروري تعليلها وتحليلها بما يسهم في التنفير من الأخلاقيات غير المسؤولة. 1 - التقنيات التصويرية توظف فيها الصورة لجذب المتلقي وإيقاعه في دائرة الحيرة بدلالات مختلفة عن المألوفة والمتبادرة لذهنه. ד ا-يتيح الخيال للطفل التجول بحرية مطلقة بين الألفاظ والعبارات والصور والرسوم، ليكون الإبداع محصلة ونتيجة للعلاقة التفاعلية بين الإبداع المعرفي

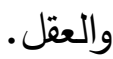
IV - يُعد الإبداع الاستعاري مجرد تصرف وتوسعة في استعارات تصويرية كامنة في الذاكرة طويلة المدى على شكل خطاطات وترابطات، لارتباطها بالنسق التصوري، المستخدم بشكل متواتر في الحياة اليومية، 


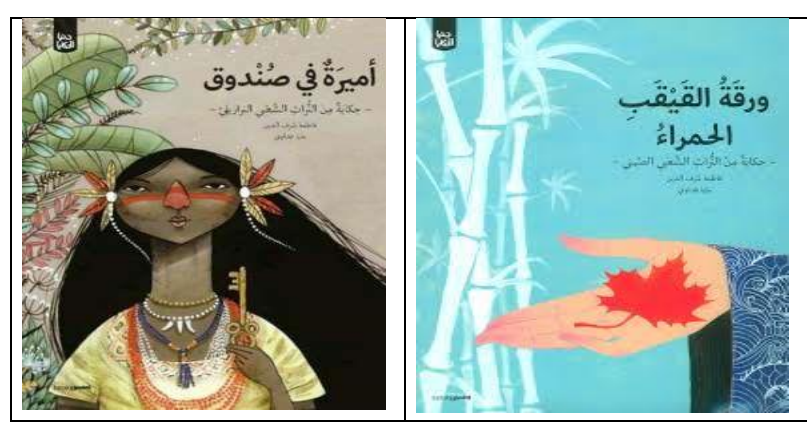

- أبو جندي، خالد (99V ام)، الجانب الفني في القصة القرآنية، د.ط، الجزائر، باتتة، دار الثهاب.

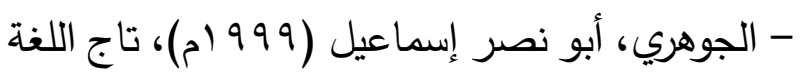

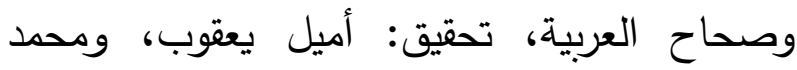
طريفي، طا بيروت: لبنان، دار الكتب العلمية.

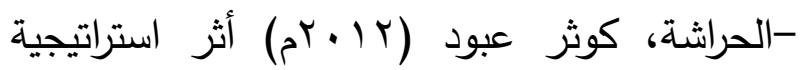
المماثلة في تدريس العلوم، في اكتساب المفاهيم

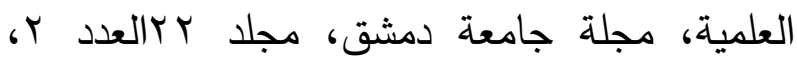

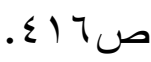

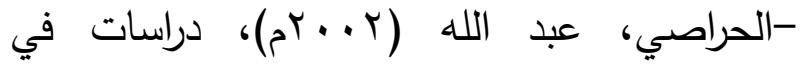
الاستعارة المفهومية، مسقط، مؤسسة عمان للصحافة

$$
\text { والأنباء والنشر • }
$$

- الزمخشري، جار الله (ب99 (1) أساس البلاغة،

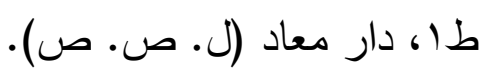

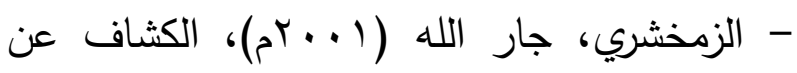
حقائق التنزيل وعيون الأقاويل في وجوه التأويل، تحقيق: عبد الرزاق المهدي، طب، بيروت، دار إحياء

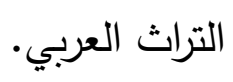

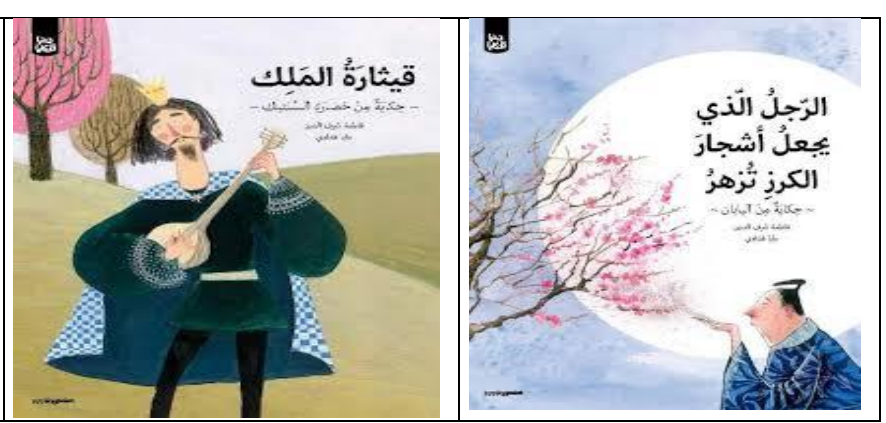

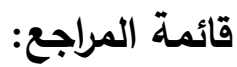

أولاً: المراجع العربية: -إبرير ، بشير (1 ( • rم)، مدخل إلى العلوم المعرفية،

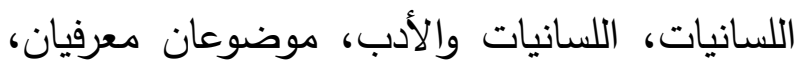
عناية، جامعة باجي مختار .

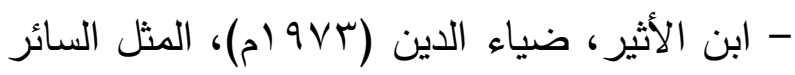

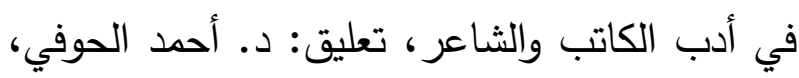
د، بدوي طبانة، القاهرة، دار نهضة مصر. - آندلر. دانييل (9 (1) بام)، العلوم المعرفية والتربية علاقة جادة، ترجمة أ.د. حافظ علوي، د.امحمد

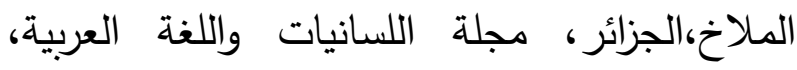

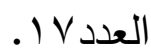

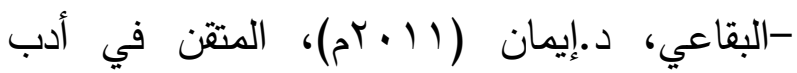
الأطفال والثباب، بيروت: لبنان،مطبعة باسيل..

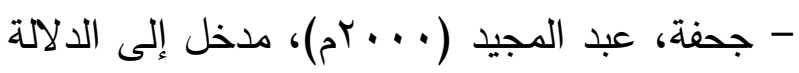
الحديثة، طا ، المغرب،دار توبقال. -جعفري، عواطف، لحمادي، فطومة (1 ( • بم) البنية الاستعارية في النص الأدبي، مقاربة عرفانية، تبسة، جامعة العربي التبسي، مجلة العلامة، العدد 7. 


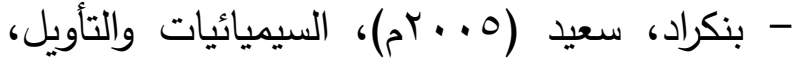
مدخل لسيميائيات. ش. س. بورس، المركز الثقافي

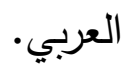

-بنكراد، سعيد ( ( . זم)، السيميائيات السردية مدخل نظري، مطبعة الزمن، الدار البيضاء.

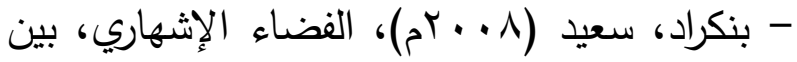
التشثيل والحلم، مجلة علامات.

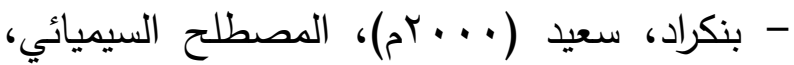
الأصل والامتداد، المغرب، مجلة علامات، العدد ع ا.

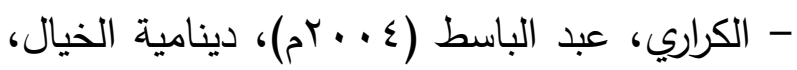
المغرب: الرباط، اتحاد الكتاب.

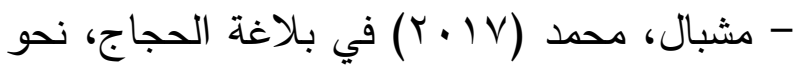
مقاربة بلاغية حجاجية لتحليل الخطاب، طا، عمان، الأردن، دار كنوز المعرفة.

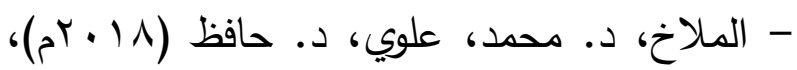
اللسانيات المعرفية والتحليل النقدي للخطاب، آفاق جديدة لدراسة السلطة، مجلة اللسانيات واللغة العربية،

- الولي، محمد. (999 ام)، الصورة الشعرية في الخطاب البلاغي والنقدي، طا، بيروت، المركز الثقافي.

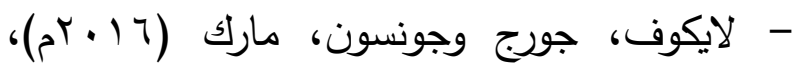
الفلسفة في الجسد. ترجمة عبد المجيد جحفة، دار الكتاب الجديد المتحدة، بيروت.
- الرباعي، عبد القادر(9V9 (م)، الصورة في النقد الأوربي، محاولة لتطبيقها على شعرنا القديم، مجلة

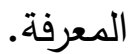

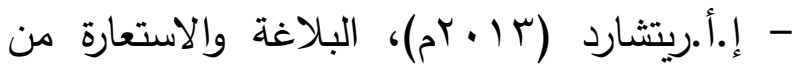
خلا كتاب فلسفة البلاغة، ترجمة: سعاد أنقار ضمن كتاب الحجاج مفهومه ومجالاته، ج) ، إعداد وتقديم حافظ إسماعيلي علوي، طا، دار الروافد، بيروت، ل ل لبنان، ودار ابن النديم، الجزائر .

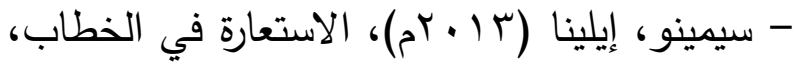
ترجمة عماد عبد اللطيف وخالد توفيق، طا، المركز

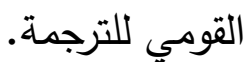
- العامري، د عبد العالي (1 إمبح)، اللغة ونظرية الذهن، مبادئ معرفية وذهنية، مجلة اللسانيات

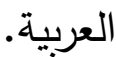
-بن عياد، محمد (r ( • rم)، في المناهج التأويلية، طا ، جامعة صفاقس، كلية الآداب والعلوم الإنسانية

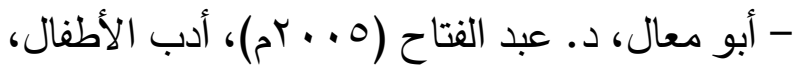
وأساليب تربيتهم وتعليمهم وتثثيفه، طا، المركز الإسلامي، مكتبة سماحة، دار الشروق. -ابن منظور، أبو الفضل جمال الدين بن مكرم

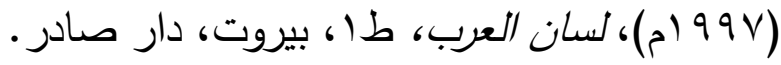
-الفيصل، سمر روحي (991 ام)، أدب الأطفال وثقافتهم قراءة نقدية، دراسة من منشورات اتحاد الكتاب

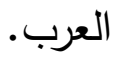

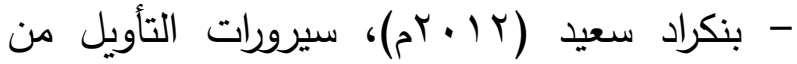
الهرموسية إلى السميائيات، الدار العربية للعلوم. 
-زلط، أحمد (997/م)، أدب الطفولة أصوله،

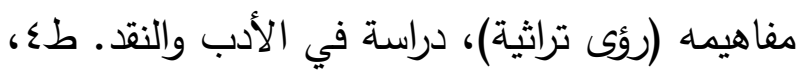
القاهرة، الثركة العربية للنشر والتوزيع.

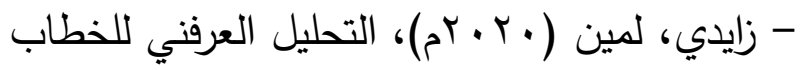
ودوره في تطوير القدرات العقلية لنتحدثي اللغة، جامعة بسكرة، جامعة العدة في اللسانيات وتحليل

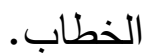

- سليم، عبد الإله (1 (. rم). بنيات المشابهة في اللغة العربية مقاربة معرفية، طا، الدار البيضاء، دار البيات توبقال للنشر . - شرف الدين، فاطمة (ع ( ب بم)، دنيا الحكايا، طا، لبنان، بيروت، بوينت للنشر والتوزيع.

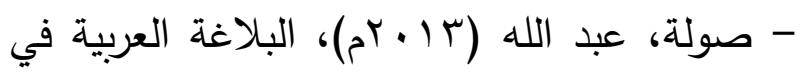
ضوء البلاغة الجديدة (أو الحجاج) ضمن كتاب

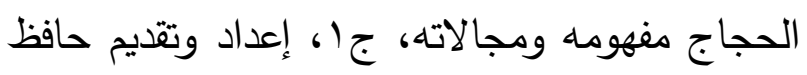

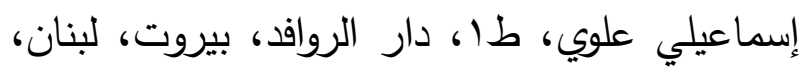
ودار ابن النديم، الجزائر.

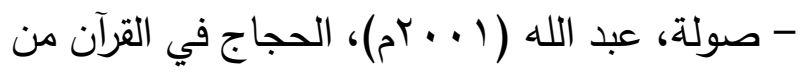
خلال خصائص أسلوبية، جامعة منوبة، كلية الآداب، تونس، جا. - علوي، حافظ إسماعيلي وآخرون (11. بام)، الحجاج والاستدلال الحجاجي دراسات في البلاغة الجديدة، طا، دار ورد الأبنية للنشر والتوزيع.

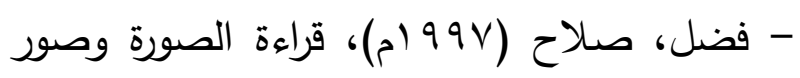
القراءة، طا، مصر ، دار الثروق.
- لايكوف، جورج وجونسون، مارك (9. (Yم)، الاستعارات التي نحيا بها، ترجمة عبد المجيد جحفة،

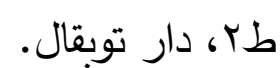
- حسن، دينا (T/ ـ آم)، أثر استخدام بعض الأدوات المعرفية، الإسكندرية: مؤتمر الإبداع وحوار الثقافات.

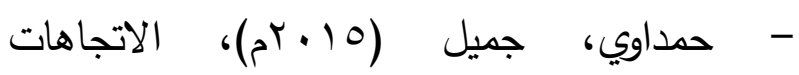
السيميوطيقية "التيارات والددارس السيميوطيقية في الثقافة الغربية "، طا، المغرب. - ضبيعي أ. النذير، عابي، أ. عبد الكنابل السلام.

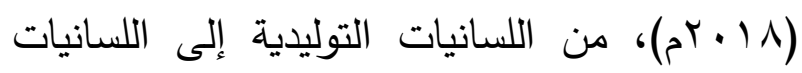
العرفانية، تحولات الدباحث والمفاهيم، الجزائر ، مركز البحث العلمي، جامعة محمد بوضياف. اللسانيات،

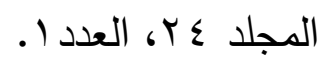

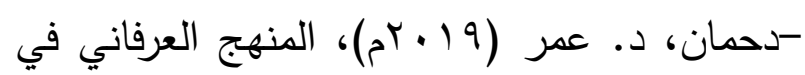

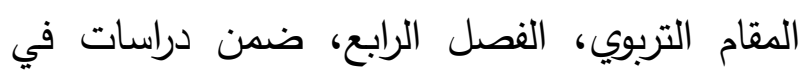

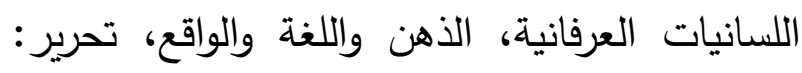
صابر الحباشة، طا، مركز الملك عبد الله لخدمة

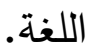
- شهاب، رافد سالم سرحان (r ا • rم)، أدب الأطفال في العالم العربي، مفهومه، نثأته أنواعه، وتطوره (دراسة تحليلية) مجلة التقني، العدد السادس.

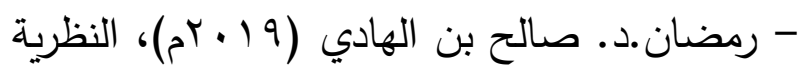
الإدراكية وأثرها في الدرس البلاغي، الاستعارة أنموذجا، ندوة الدراسات لبلاغية - الواقع والمأمول. 
- مكرم، عبد الودود (799 (1)، الأصول التربوية لبناء الشخصية المسلمة، القاهرة، دار الفكر العربي. - ملكاوي، فتحي (11 (1)م)، منهجية التكامل المعرفي، مقدمات في المنهجية الإسلامية، المعهد العالمي للفكر الإسلامي. - موقو، د. عفاف (9 (1) (بم)، ملامح من الأبنية

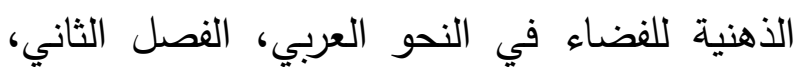
ضمن دراسات في اللسانيات العرفانية، الذهن واللغة والواقع، تحرير: صابر الحباشة، طا، مركز الملك

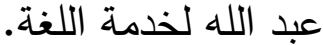

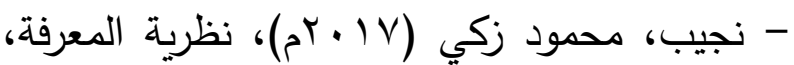
مؤسسة هنداوي.

-نعيم، علوية (1911م)، بحوث لسانية بين نحو اللسان ونحو الفكر، طب، لبنان، بيروت، المؤسسة

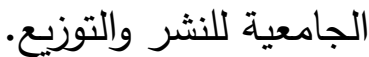

- بن بحيى، د. ناعوس، (1 ا • rم) حجاج البلاغة، وبلاغة الحجاج، الجزائر، مجلة الدراسات الأدبية

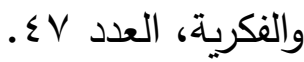

ثانياً: المراجع الأجنبية: -Anscombre et Ducrot, 1 'argumentation dans la langue.

-Barthes, (The Photographic Message,) in: Barthes: Image, Music, Text.

-Johnson, M, The Body in the Mind: The Bodily Basis of Meaning, imagination and
- فضل، صلاح (199 (م)، بلاغة الخطاب وعلم

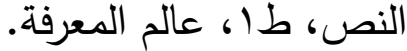
- كلارك، ديفيد، نرليش، بريجيت (V) (IT) اللسانيات الإدراكية وتاريخ اللسانيات، ترجمة: د. حافظ إسماعيلي علوي، مجلة أنساق، قطر كلية

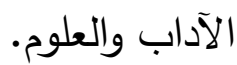
-كيليطو، عبد الفتاح (910 (م)، الحكاية والتأويل، دراسة في السرد العربي، الدار البيضاء: دار توبقال • للنشر

-مخلوف، سمير أحمد (•(+rم)، الصور الذهنية (دراسة في تصور المعنى)، مجلة جامعة دمشق،

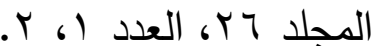

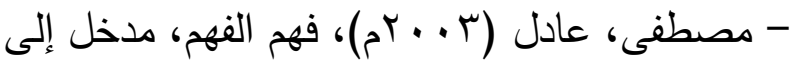
الهرمنيوطيقا: نظرية التأويل من أفلاطون إلى جادامر، مؤسسة هنداوي. - مصلوحي، سميرة (9 1 • بم) السخرية في الخطاب القرآني، مقاربة حجاجية تداولية، مذكرة دكتوراه، الرباط، جامعة محمد الخامس. - مصمودي، د. وسمية نجاح (V I • rم)، المقاربات العرفانية وتحديث الفكر البلاغي، طالأردن، دار

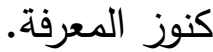

Reason. Chicago: Chicago university press. 1987, xiv.

-Giambattista Vico, The New Scince of Giambttista Vicon, Translated (18) by Thomas Goddard Bergin and Max Harold Fisch (Ithaca, N.Y.:Cornell University Press, 1744) . 
Cf. William Croft \& D.Alan Cruse: Cognitive Linguistics.

-Responsibility of Forms: critical Essaya on Music, Art, and Representation.

-Ryle, Gilbert. The Concept of Minnd. Routledge (2009) .

-V yvyan Evans and Melanie Green: Cognitive Linguistics. An Introduction, p3.

-joelle gardes - tamine pour une nouvelle theorie des figures, puf, 2011.

-Marc Bonhomme, "De I argumentativite des figures de rhétorique", -op, Argumentation et cit Analyse du Discours (En ligne), 2/ 9009, mis en ligne le 01 avril 2009, consulte le 16 septembre 2013.

- Vyvyan Evans and Melanie Green, Cognitive linguistics an introduction, Lawson, A. (1993).The Importance of Analogy: A Prelude to the Special .

-Mandler, J. 2004, the Foundations of Mind: Origins of Conceptual Thought Oxford, University Press.

https://www.alukah.net/literature_language/0/1 09292/\#ixzz6OHUCt8B9- 
تصوير المعرفة والقيم في قصص الأطفال مجموعة دنيا الحكايا نموذجا

\title{
Depiction of Knowledge and Values in Children's Stories Dunya Al-Hekaya Collection as a Model
}

\author{
Dr. Fathia Bedairi \\ King of Saudi Arabia \\ University of Jeddah
}

\begin{abstract}
Depiction of the image, with its attractive expressions and its artistic heritage statements, in childhood stories with its cognitive and value aspects, plays an important role in introducing the fixed core elements that help clarify and approximate the meaning to the child. This depiction is an important factor that impacts the methods of perception and thought, as it is represented in heritage stories by various methods and ways that contribute to establishing and enhancing Educational values, including the indicative aesthetics in expressing the child's desires and needs, as they are messages from the storyteller to the child to guide him.Then, this study tries to find a tendency aimed at cognitive science as a basis for the scientific methodology in education, in an attempt to balance between educational values and the scientific aspect; and to determine the extent of the compatibility of these images with the child's culture and society and how they influence his conscience to satisfy his desires and needs, including the aspects of argumentation and persuasion.

This study aims to discover the values that the image has and their strengths in argumentation, and to identify the depiction's contribution to bringing knowledge closer. The achievement of this aim leadsto dominate child's thought and behavior, in the context of the cognitive approach and in an interactive framework according to the methods of their presentation in the child's story collection. The treatment material represented: a story collection of different peoplesheritage, in which images were used to attract the child's attention focusing on depicting the values directed to the child as the language enhances his relationship with those around him. The study concluded with a set of results, including that the cognitive analysis of the stories gives deep meanings. The aim of this analysis is to know the mechanisms that contributes to providing the child with different values, stresses the need to change unwanted behaviors and reject violence with various linguistic and non-linguistic means
\end{abstract}

